NBER WORKING PAPER SERIES

\title{
UNDEREMPLOYMENT IN THE EARLY CAREERS OF COLLEGE GRADUATES FOLLOWING THE GREAT RECESSION
}

\author{
Jaison R. Abel \\ Richard Deitz \\ Working Paper 22654 \\ http://www.nber.org/papers/w22654
NATIONAL BUREAU OF ECONOMIC RESEARCH
1050 Massachusetts Avenue
Cambridge, MA 02138
September 2016

Prepared for NBER/CRIW conference on "Education, Skills, and Technical Change: Implications for Future U.S. GDP Growth.” We thank Chuck Hulten, Valerie Ramey, Till von Wachter, and the CRIW participants for helpful comments. The views and opinions expressed here are solely those of the authors and do not necessarily reflect those of the Federal Reserve Bank of New York, the Federal Reserve System, or the National Bureau of Economic Research.

NBER working papers are circulated for discussion and comment purposes. They have not been peer-reviewed or been subject to the review by the NBER Board of Directors that accompanies official NBER publications.

(C) 2016 by Jaison R. Abel and Richard Deitz. All rights reserved. Short sections of text, not to exceed two paragraphs, may be quoted without explicit permission provided that full credit, including $(\odot$ notice, is given to the source. 
Underemployment in the Early Careers of College Graduates Following the Great Recession Jaison R. Abel and Richard Deitz

NBER Working Paper No. 22654

September 2016

JEL No. I23,J23,J24,J62

\section{$\underline{\text { ABSTRACT }}$}

Though labor market conditions steadily improved following the Great Recession, underemployment among recent college graduates continued to climb, reaching highs not seen since the early 1990s. In this paper, we take a closer look at the jobs held by underemployed college graduates in the early stages of their careers during the first few years after the Great Recession. Contrary to popular perception, we show that relatively few recent graduates were working in low-skilled service jobs, and that many of the underemployed worked in fairly well paid non-college jobs requiring some degree of knowledge and skill. We also find that the likelihood of being underemployed was lower for those with more quantitatively oriented and occupation-specific majors than it was for those with degrees in general fields. Moreover, our analysis suggests that underemployment is a temporary phase for many recent college graduates as they transition to better jobs after spending some time in the labor market, particularly those who start their careers in low-skilled service jobs.

Jaison R. Abel

Research and Statistics Group

Federal Reserve Bank of New York

33 Liberty Street

New York, NY 10045

jaison.abel@ny.frb.org

Richard Deitz

Research and Statistics Group

Federal Reserve Bank of New York

33 Liberty Street

New York, NY 10045

richard.deitz@ny.frb.org 
"Welcome to the Well-Educated Barista Economy"

--The Wall Street Journal, April 2014

\section{INTRODUCTION}

The image of a young newly minted college graduate working behind the counter of a hip coffee shop has become a hallmark of the plight of college graduates following the Great Recession. Indeed, although economic conditions steadily improved through the recovery, significant slack remained in the labor market, and many recent graduates were not finding jobs commensurate with their education. The underemployment rate for recent college graduates - that is, the share working in jobs that typically do not require a college degree-continued to climb for several years following the Great Recession, topping out at nearly 50 percent, a level not seen since the early 1990s.

While underemployment among recent college graduates has attracted wide attention in the media and among policymakers, very little is actually known about the nature of college underemployment or what seems to make some college graduates more prone to being underemployed than others. ${ }^{1}$ In this paper, we examine the plight of college graduates in the aftermath of the Great Recession. We examine in detail the types of jobs underemployed college graduates hold, and explore some of the factors associated with a greater likelihood of being underemployed.

For example, a 2012 Associated Press article with the headline "Half of New Grads are Jobless or Underemployed," reignited an intense debate about the value of a college degree. Headlines such as "College Grads May Be Stuck in Low-Skill Jobs," (WSJ, 2013) and "Welcome to the Well-Educated Barista Economy," (WSJ, 2014) became commonplace after the Great Recession. 
We conclude that while there is some truth behind the popular image of the college-educated barista, this picture is not an accurate portrayal of the typical underemployed recent college graduate. Contrary to popular perception, we show that only a small fraction of recent graduates worked in a low-skilled service job following the Great Recession. Instead, we find that underemployed recent graduates held a wide range of jobs, and while most are clearly not equivalent to jobs that require a college degree, some are fairly skilled and well paid. In addition, we find that underemployed college graduates were more likely to be working in these higher paying non-college jobs than similarly aged young workers without a college degree. Still, we find that roughly 9 percent of recent graduates - or about one-fifth of the underemployed — start their careers working in a low-skilled service job.

We then explore the characteristics of underemployed recent college graduates, and examine correlates associated with being underemployed or working in a low-skilled service job. We find that men are more likely to be underemployed than women, though a larger share of underemployed men work in the highest-paying non-college jobs. Further, we show that underemployment is far more likely for recent graduates with some college majors compared to others. For example, those with majors in Liberal Arts or General Business are two to three times more likely to be underemployed than those with Engineering or Nursing majors. The patterns we uncover suggest that those recent graduates who major in more quantitatively oriented and occupation-specific fields tend to have much lower underemployment than those with majors that are more general. Finally, our analysis suggests that underemployment is a temporary phase for a good number of recent graduates, particularly among those who start their careers working in a 
low-skilled service job, as many transition to better jobs after spending a few years in the labor market.

Though underemployment appears to have become increasingly prevalent in the labor market, particularly among college graduates, only a small body of research on the subject currently exists. Much of this research focuses on underemployment among reemployed workers following layoffs, or those who work in part-time or temporary positions (see, e.g., Feldman, 1996 and McKee-Ryan and Harvey, 2011). In addition, much of the existing underemployment literature emphasizes the emotional and psychological effects of underemployment, rather than its economic consequences. An early exception is Feldman and Turnley (1995), who study underemployment among a small sample of recent college graduates with business degrees, and more recently, Abel, Deitz, and Su (2014) provide some historical context by examining underemployment among recent college graduates over the past few decades. Our work builds on this small body of research by providing a more detailed analysis of the types of jobs held by underemployed graduates in the early stages of their careers, and by identifying the factors that make some graduates more prone to underemployment than others.

One strand of the literature that is closely related to underemployment examines over-education in the labor market (see, e.g., Hersch, 1991; Chevalier, 2003; Chevalier and Lindley, 2009; and Green and Zhu, 2010). However, unlike our work, this research typically relies on self-reported measures of whether there is a match between a worker's education and job to assess the extent and economic effects of over-education.

Our work is also related to a small but growing literature documenting the economic consequences of graduating from college during recessions (see, e.g., Kahn, 
2010; Oreopoulos, von Wachter, and Heisz, 2012; and Altonji, Kahn, and Speer, 2016). This research indicates that adverse labor market conditions in the early careers of college graduates can have significant long-term effects on earnings, and shows that these negative effects differ greatly by college major and ability. These studies generally do not directly examine the types of jobs graduates obtain in the early stages of their careers. However, differences in the quality of the initial placement of graduates with more challenging college majors or higher ability is believed to be an important contributor to differences in longer-term employment outcomes. Our work provides some support for this explanation by documenting that recent graduates with college majors that provide technical training and quantitative skills are far less likely to be underemployed in the early stages of their careers than those with majors that tend to be less quantitative in nature.

Indeed, the role of college major in finding a good job has become of considerable interest in recent years given the weak labor market following the Great Recession. Recent research has documented significant heterogeneity in the labor market outcomes of college graduates with different majors (see, e.g., Altonji, Blom, and Meghir, 2012 and Altonji, Kahn, and Speer, 2014, 2016), and information on labor market outcomes by major has been shown to influence the choices students make while in college (see, e.g., Betts, 1996; Zafar, 2013; and Wiswal and Zafar, 2015a, 2015b). Our work adds to this body of research by providing new information about how one's college major is associated with an understudied labor market outcome - the likelihood of being underemployed upon graduation. Further, we are able to examine labor market outcomes for a more detailed set of college majors than has previously been studied. 


\section{THE LABOR MARKET FOR COLLEGE GRADUATES FOLLOWING THE GREAT RECESSION}

The Great Recession was the deepest downturn experienced in the United States in the postwar era, and its effects on the labor market were swift and severe. Though labor market conditions started to improve in early 2010 , the recovery that followed was slow and uneven, resulting in a large amount of slack that persisted for an extended period of time (see, e.g., Elsby et al., 2010, 2011 and Şahin et al., 2014). Those unlucky college graduates who started their careers in the aftermath of the Great Recession struggled to find jobs, let alone jobs that utilized their degrees. Much of this difficulty can be traced to relatively weak labor demand for college graduates during the recovery.

\section{A. Unemployment Among College Graduates}

Though college graduates generally weathered the economic storm better than those without a degree, they were not immune from its effects. As Figure 1 shows, unemployment rose sharply during the Great Recession and continued to climb in the early stages of the recovery to levels not seen in decades. Figure 1 also shows the unemployment rate for recent college graduates. For the purposes of our analysis, we define recent college graduates as those with at least a bachelor's degree who are 22 to 27 years old. We select this group to capture college graduates within their first five years after graduation who are at the beginning of their careers. ${ }^{2}$

2 The typical age at which people earn a bachelor's degree in the United States is 22. While some graduates receive their degree at ages beyond their early twenties, data limitations do not allow us to identify these older graduates. We exclude those in the military and individuals enrolled in school, whether full-time or part-time, to avoid confusion about whether someone's employment status is influenced by whether they are attending school. 
Unemployment among recent college graduates, who are often more susceptible to cyclical changes in the labor market than college graduates as a whole, doubled from about 3.5 percent before the recession to a peak of more than 7 percent in 2011 . However, unemployment among recent college graduates began to fall in late 2011, and generally continued to trend down thereafter. Even with this progress, unemployment among recent college graduates fell less steeply than for college graduates as a whole, underlying the more negative effects of labor market conditions for recent graduates compared to their more seasoned counterparts.

\section{B. Underemployment Among College Graduates}

While the unemployment rate has declined, such a statistic reveals only part of the story about the plight of recent college graduates following the Great Recession. Indeed, the weak labor market prompted widespread concern that recent graduates were underemployed - that is, working in jobs that typically do not require a college degree (see, e.g., Fogg and Harrington, 2011; Yen, 2012; and Vedder, Denhart, and Robe, 2013).

We measure the underemployment rate as the share of employed college graduates working in jobs that do not require a college degree. To distinguish between college jobs and non-college jobs, we rely on the Department of Labor's O*NET database. ${ }^{3} \mathrm{O}$ NET contains occupation-level data for hundreds of occupations collected via interviews of incumbent workers and input from professional occupational analysts on a wide array of job-related requirements. We use the following question from the O*NET Education and Training Questionnaire to determine whether an occupation

\footnotetext{
3 We use O*NET Version 18.1 for our analysis, see http://www.onetcenter.org/ for more information.
} The O*NET database is discussed in detail by Peterson et al. (2001). 
requires a college degree: "If someone were being hired to perform this job, indicate the level of education that would be required?" (emphasis added). Respondents then select from twelve detailed education levels, ranging from less than a high school diploma to post-doctoral training. We consider a college education to be a requirement for a given occupation if more than 50 percent of the respondents working in that occupation indicated that at least a bachelor's degree was necessary to perform the job. ${ }^{4}$

We show the underemployment rate in Figure 2 for both recent college graduates and college graduates as a whole. The underemployment rate for recent college graduates consistently holds well above the rate for all college graduates, which has hovered at around one-third for at least the past 25 years, reflecting the challenges faced by newly minted graduates as they enter the labor market. Focusing on the period following the Great Recession, apart from a brief dip in early 2011, the underemployment rate for recent college graduates continued to climb well into 2014, rising to more than 46 percent, a level not seen since the early 1990s. This divergence between falling unemployment and rising underemployment among recent college graduates between mid-2011 and mid-2014 suggests that more graduates were finding jobs during this time, just not necessarily good ones.

Of note, underemployment is not a new phenomenon facing young graduates in recent years. Indeed, underemployment among recent college graduates was on an upward trend for several years before the Great Recession. While there appears to be a cyclical component to underemployment among recent college graduates, the broader V-

4 We selected this threshold because it indicates that the majority of respondents believe that at least a bachelor's degree is required to perform a given job. In practice, however, few occupations are clustered around the 50 percent threshold. For most occupations, respondents either overwhelmingly believe that a bachelor's degree is required for the job or not. 
shaped pattern in the underemployment rate over the past 25 years is also consistent with recent research by Beaudry, Green, and Sand $(2014,2016)$ arguing that there has been a reversal in the demand for cognitive skills since 2000. According to this research, businesses ramped up their hiring of college-educated workers in an effort to adapt to the technological changes occurring during the 1990s. However, as the information technology revolution reached maturity, demand for cognitive skill fell accordingly. As a result, during the first decade of the 2000s, many college graduates were forced to move down the job ladder to take jobs typically performed by lower-skilled workers. From this perspective, the relatively low underemployment rates among recent college graduates at the peak of the technology boom around 2000 may in fact be an outlier, while the rise in underemployment since then represents a return to more typical conditions.

\section{The Demand for College Graduates After the Great Recession}

To gain a better understanding of what is behind recent patterns in both unemployment and underemployment among college graduates, we measure the availability of college jobs and non-college jobs around the Great Recession. We use data on online job postings from The Conference Board's Help Wanted OnLine (HWOL) database, which provides information on the full universe of online job postings during this period and serves as a comprehensive measure of labor demand. ${ }^{5}$ We use monthly data measuring total advertised job postings. Importantly, for our purposes, the HWOL database assigns a detailed occupation code to each advertised posting. We use these

5 Advertised job vacancies are collected from more than 16,000 online job boards, including corporate job boards, and efforts are made to remove duplicate postings. See https://www.conferenceboard.org/data/helpwantedonline.cfm for more information on the HWOL database. Because the earliest available HWOL data start in 2005, we are not able to examine the extent to which the demand for college graduates started to decline around 2000, as suggested by Beaudry, Green, and Sand (2014, 2016). 
occupation codes to distinguish between college jobs and non-college jobs using the O*NET classification defined previously.

The trend in job postings for both types of jobs is shown in Figure 3. Although postings for college jobs and non-college jobs rebounded at roughly the same pace immediately following the Great Recession, by 2011 the demand for college graduates began to fall behind. In fact, postings for college jobs leveled off around 2013, and even declined slightly through mid-2014, while postings for non-college jobs continued to rise at a fairly steady clip throughout the recovery.

The steady growth of non-college jobs, coupled with the relatively soft demand for college graduates during this three-year period, appears to have forced many recent college graduates to take jobs not commensurate with their education. With the demand for college graduates rising again beginning in mid-2014, underemployment also started to come down. However, even with this modest improvement, 44.6 percent of college graduates - nearly one in two - found themselves underemployed in the early stages of their careers following the Great Recession. However, these data reveal little about the types of jobs these underemployed workers were performing.

\section{ARE ALL UNDEREMPLOYED COLLEGE GRADUATES WORKING AS BARISTAS?}

To provide a deeper understanding of the types of jobs held by underemployed recent college graduates in the years following the Great Recession, we turn to the American Community Survey (ACS), a nationally representative one percent sample of the population conducted on an annual basis (Ruggles et al., 2015). These data include a variety of detailed economic and demographic information for individuals, including a 
person's occupation, wage, and education. We pool annual data for the years 2009 to 2013, leaving us with a roughly 5 percent random sample of the U.S. population.

Our sample of recent college graduates contains nearly 180,000 observations representing more than 20 million individuals during the 2009 to 2013 period. For comparison purposes, we also construct a parallel sample of young workers aged 22 to 27 without a college degree. This sample contains roughly 346,000 observations representing about 44 million individuals over this same period. Because men and women may choose different career paths or have different experiences in the labor market, we perform all of our analyses overall and separately by gender.

\section{A. $\quad$ Types of Jobs Held by Underemployed College Graduates}

What types of jobs are underemployed recent graduates performing, and how common is it for such workers to be stuck in a low paying job, such as a coffee house barista? To address these questions, we create ten underemployed occupation categories from the hundreds of detailed occupation codes identified in the data. In forming these occupation categories, we attempted to create groups with a reasonably comparable set of knowledge and skill requirements based on the nature of the work performed. In some cases, we also used average wages earned in these detailed occupations to assign them to these categories. Table 1 displays these groupings together with the average wage paid to all workers in each group, not just recent college graduates. ${ }^{6}$

6 We focus on the average wages of all workers in these occupation categories to give a general sense about the relative differences in skill levels across the categories we create. While recent college graduates tend to earn less than these figures, largely because such workers are in the early stages of their careers, the pattern for recent graduates is similar to that for all workers. 
These occupation categories fall into six tiers based on how well jobs in each group tend to pay. The first tier contains two groups of relatively high paying jobs, where workers on average earn more than $\$ 55,000$ per year. The highest-paying occupation category, Information Processing and Business Support, tends to emphasize cognitive skills, and workers in these jobs typically work with technology, use or produce information in their jobs, and often play a supporting role to others within their line of business. Examples of the kinds of jobs included in this category are human resource workers, computer support specialists, web developers, computer network architects, and paralegals. The next highest paying category is Managers and Supervisors, which includes workers who have direct oversight of other employees within their organization, and are often responsible for managing part of a business. Some decision making is typically required in these types of jobs, but such decisions are often fairly limited in scope. Examples of jobs that fall within this category include first-line supervisors of various types of workers (e.g., retail sales, administrative support, and production) and food service managers.

The second tier of underemployed occupation categories tend to pay between $\$ 50,000$ and $\$ 55,000$ per year, and includes Public Safety and Sales jobs. Jobs in the Public Safety category emphasize a combination of physical and cognitive skills, and workers in these types of jobs tend to protect and serve the public. Examples of the kinds jobs included in this category are police officers, detectives, security guards, and firefighters. Jobs in the Sales category tend to require strong interpersonal skills and the ability to interact with customers. Workers in these jobs are responsible for selling a wide array of goods and services, ranging from physical products found on the shelves of retail 
stores to insurance policies and real estate. Examples of the kinds of jobs included in this category are sales representatives, insurance agents, real estate brokers, as well as retail salespersons. $^{7}$

The third tier of underemployed occupations pays, on average, around $\$ 48,000$, and includes Arts and Entertainment and Skilled Trades. Workers in these jobs are often highly skilled, but these are not the types of skills typically developed by earning a college degree. Examples of the types of jobs captured in this tier include professional athletes, musicians, actors, and dancers, as well as electricians, machine repairers, plumbers, and welders.

The fourth tier has average annual earnings ranging between $\$ 35,000$ and $\$ 40,000$. This tier includes two groups. First, Office and Administrative Support, which tends to emphasize clerical knowledge, oral and written communication skills, and basic proficiency with computers. While some cognitive skills are required, the demands are typically below what is required of workers in Information Processing and Business Support jobs. Examples of jobs in this category include secretaries, customer service representatives, and office clerks. Second, this tier includes Healthcare Technicians and Assistants. Workers in these jobs provide care for others, but typically in a role that supports a healthcare practitioner. Many of these jobs require an associate's degree or some other type of training certificate. Examples of the jobs in this category are medical assistants, nursing aides, diagnostic technicians, and dental hygienists.

While retail sales jobs might be viewed as similar to low-skilled service jobs, retail sales jobs tend to require more skill, particularly in the areas of communication and persuasion, and pay significantly higher wages, even for young college graduates. 
The fifth tier consists of Physical Laborers. Jobs in this category tend to emphasize the physical dimension of a worker's skill set, such as strength, agility, and dexterity. Examples of jobs in this category include construction laborers, truck drivers, roofers, and highway maintenance workers.

Finally, the lowest-paying tier consists of Low-Skilled Service jobs, which tend to pay around minimum wage. ${ }^{8}$ These are the types of jobs that, rightly or wrongly, have become the poster child for underemployed young college graduates in recent years. Examples of the kinds of jobs found in this category are waiters and waitresses, cashiers, bartenders, cooks, and, yes, baristas.

While demand in the non-college segment of the labor market doubled in the years following the Great Recession, this growth was not merely in low-paying jobs. We turn back to the HWOL database to provide estimates of the number and growth of monthly job postings for each of the occupation categories identified above between 2009 and 2013, also shown in Table 1. The Managers and Supervisors category had the largest number of job postings after the Great Recession, followed closely by Office and Administrative Support. The two lowest-paying categories, Physical Laborers and LowSkilled Service, saw large increases in demand, as did Skilled Trades and Managers and Supervisors. These figures suggest that while many low-skilled service jobs were available during this time, there were plenty of opportunities in jobs that tended to pay higher wages. Next, we examine which jobs both underemployed college graduates and those without college degrees took.

Autor and Dorn (2013) demonstrate that growth in these types of jobs has been strong in recent decades, which has contributed to the polarization of the U.S. workforce. 


\section{B. What Jobs Did Underemployed Graduates Take?}

Table 2 shows the share of underemployed recent college graduates across the ten occupation categories in the years following the Great Recession. Contrary to popular perception, most underemployed recent college graduates were not working in lowskilled service jobs. Indeed, nearly half were working in relatively high-paying jobs, with more than 10 percent each working in the Information Processing and Business Support, Managers and Supervisors, and Sales categories. At 25 percent, the largest share of underemployed workers were employed in the Office and Administrative Support category. While these jobs may not be as desirable as the typical college job, which pays around $\$ 78,500$ annually, they are significantly better than low-skilled service jobs. That said, about one-fifth of underemployed recent college graduates-roughly 9 percent of all recent graduates—-were working in a low-skilled service job. ${ }^{9}$

Comparing the distribution of underemployed college graduates to young workers of the same age without a college degree yields some important insights about the value of a college degree for underemployed workers. Those with a college degree were much more likely to be working in higher paying jobs than those without. This pattern is particularly evident in the highest-paying occupation categories that tend to emphasize cognitive skills and decision making, such as the Information Processing and Business Support and Managers and Supervisors categories. While around 40 percent of recent college graduates were employed in the two highest paid tiers of non-college occupations, only 18 percent of young workers without degrees held these types of jobs.

\footnotetext{
9 As an alternative to the Low-Skilled Service category, we also measured the share of all underemployed workers earning around the minimum wage. We estimate this share to be roughly 20 to 25 percent, comparable to the share working in a low-skilled service job.
} 
By contrast, among those working in these occupational categories, more than half of young workers without a college degree were working in the low-paying Physical Laborers and Low-Skilled Service occupation categories, double the share for recent college graduates. Moreover, though not shown in the table, we also find that underemployed recent college graduates tend to earn more than similarly aged young workers without a college degree within each occupation category.

While the same general patterns hold between the genders, there are some notable differences, as shown in Table 3. Underemployed men are more likely to be working in the highest-paying occupation categories, including Information Processing and Business Support and Managers and Supervisors. The male-female ratio is also particularly large for jobs in the Public Safety and Skilled Trades categories, both of which tend to emphasize physical skills. By contrast, underemployed women are much more likely to be working in Office and Administrative Support jobs, and, to a lesser extent, the Healthcare Technicians and Assistants category. In terms of the lower-paying categories, underemployed men are more likely than women to be working in jobs in the Physical Laborers category, while underemployed women are more likely to be working in jobs in the Low-Skilled Service category.

\section{WHICH GRADUATES ARE MORE PRONE TO UNDEREMPLOYMENT?}

We next turn to the question of which recent college graduates are more likely to be underemployed. We use probit regressions to reveal which characteristics of recent college graduates are associated with a higher probability of being underemployed, with a particular focus on college major. Because men and women may choose different career paths or have different experiences in the labor market, we estimate our regression 
models using aggregate data and separately by gender. We wish to emphasize that our models are not meant to imply causation, but rather to uncover some of the correlates to the likelihood of being underemployed based on the characteristics of workers we are able to identify in the data we employ.

\section{A. Estimation Approach}

Because our measures of underemployment are binary variables, we use probit models to estimate the likelihood of underemployment among recent college graduates. Specifically, letting $\mathrm{UNDER}_{i}$ represent the underemployment of individual $i$ located in state $j$ during year $t$, the probability that an individual is working in a job that does not require a college degree can be expressed as:

$$
\operatorname{Prob}\left(\mathrm{UNDER}_{i}=1\right)=\Phi\left(\beta \mathbf{X}_{i}+\delta \mathbf{M}_{i}+\phi_{j}+\phi_{t}\right)
$$

where $\mathbf{X}_{i}$ is a vector of individual-level worker characteristics, $\mathbf{M}_{i}$ is a vector of dummy variables denoting an individual's college major, $\phi_{j}$ is a state-level spatial fixed effect, $\phi_{t}$ is an annual time fixed effect; and $\beta$ and $\delta$ are parameters to be estimated. $\Phi(\cdot)$ is a normal cumulative distribution function, and the estimated parameters are chosen to maximize the sum of the log likelihoods over all observations. We estimate our models using two different measures for $\mathrm{UNDER}_{i}$, one that broadly includes graduates working in any non-college job, and a second more narrowly-defined measure of underemployment for those working in the Low-Skilled Service category.

Of particular interest for our purposes, the ACS began to include information on an individual's undergraduate degree major starting in 2009. Specifically, the ACS provides information for more than 170 detailed degree major categories. Since many of 
these detailed majors contain relatively few observations, we collapse this list into 73 majors to preserve large enough sample sizes to obtain meaningful results.

To explore how differences in worker characteristics, $\mathbf{X}_{i}$, are related to the likelihood of underemployment, our probit models include a wide range of individual level characteristics such as gender, age, marital status, the presence of children, race and ethnicity, and disability status. ${ }^{10}$ In addition, when collecting information about college major, the ACS allows individuals to list up to two majors. We consider those individuals who listed two majors as having graduated with a double major, which we control for, and count the first listed as that person's college major. As another control, we are also able to identify recent college graduates who have earned a graduate degree. ${ }^{11}$

Table 4 provides descriptive statistics for the worker characteristics included in our study for three groups: all recent college graduates, those who are underemployed, and those working in a low-skilled service job. Interestingly, there are more underemployed women (55 percent) than men (45 percent). This differential partly reflects the fact that there are now more women college graduates than men in the overall population, though men seem to be slightly overrepresented among the underemployed. By contrast, men are underrepresented among low-skilled service workers. About 20 percent of the underemployed are married, 8 percent have children, 12 percent graduated with a double major, and 6 percent earned a graduate degree. Proportionally fewer recent

10 To allow for non-linear effects from gaining experience in the labor market, we follow the convention in wage studies and include both age and age-squared in our models.

11 The ACS indicates whether an individual holds a master's degree, professional degree, or doctoral degree, but does not provide information about the type of graduate degree (e.g., MA, MBA, JD, MD) or course of study while in graduate school. 
college graduates working in a low-skilled service job were married, had children, graduated with a double major, or earned a graduate degree.

To account for differences in local economic conditions across time and space which may influence the likelihood of being underemployed, we include state-level spatial fixed effects, $\phi_{\mathrm{j}}$, and annual time fixed effects, $\phi_{t}$, in our models. ${ }^{12}$ In all of our analysis, we report robust standard errors clustered at the state level, which tends to increase standard errors but does not affect the point estimates themselves.

Despite our efforts to control for differences in local economic performance and a wide range of individual worker characteristics, care must be taken when interpreting our findings. Most significantly, in part, students sort into their chosen field of study based on their ability to complete the required coursework (see, e.g., Arcidiacono, 2004 and Zafar, 2011, 2013). Thus, not all majors are feasible for every college student, and graduates with different majors likely differ in other important ways that we are unable to measure, such as intelligence, perseverance, or motivation. Indeed, recent research has shown that graduating with a math or science major is more difficult than other fields of study (Stinebrickner and Stinebrickner, 2014). In addition, our results represent average outcomes for graduates within each of the 73 college majors we analyze. Thus, by definition, some individuals within each major will have better or worse outcomes than

For example, Mian and Sufi $(2010,2011)$ show that the most pronounced effects of the Great Recession were concentrated in the 'Sand States,' and that the pace of recovery generally differed across states. Further, Abel and Deitz (2015) show that local labor market conditions can influence the likelihood and quality of the match between an individual's education and job. We also estimated a model using spatial fixed effects at the local labor market area, which we defined as metropolitan areas and the rural portion of each state. Results were nearly identical to those reported in the paper, but small sample sizes within many local labor markets prevented us from estimating models using underemployed graduates working in low-skilled service jobs. 
our results suggest. Nonetheless, examining the typical experience within each major can provide useful insights into the correlates of the likelihood of underemployment.

\section{B. Estimation Results}

Because of the difficulties associated with interpreting raw coefficient estimates obtained via probit analysis, we instead present the corresponding average marginal effects and predicted probabilities obtained from our analysis. As such, our estimates can be interpreted as the average percentage point change in the probability of either being underemployed or working in a low-skilled service job. We first describe how the probability of being underemployed is correlated with the worker characteristics we are able to identify, and then turn to the role of college major.

\section{i. Worker Characteristics}

Table 5 presents the average marginal effects associated with the worker characteristics included in our analysis. Columns (1)-(3) show results using underemployment in general as the dependent variable, while Columns (4)-(6) show results using Low-Skilled Service jobs only. Our results show that the likelihood of college underemployment differs significantly across a wide range of worker characteristics.

Regarding gender differences, our analysis indicates that male graduates are 1.2 percentage points more likely to be underemployed in the early stages of their careers than their female counterparts. Specifically, men have a predicted probability of 45.3 percent compared to 44.1 percent for women-a gap that represents about a 3 percent difference between these groups. This difference may stem in part from the recent success women have enjoyed relative to men while in college, but it could also reflect the 
fact that underemployed men tend to be more represented in the higher-paying noncollege occupation categories, and, therefore may have less incentive to seek a college job. ${ }^{13}$ Indeed, women graduates are 1.1 percentage points (9.1 percent compared to 8.0 percent) more likely to be working in a low-skilled service job than men-a difference of more than 12 percent. For both men and women, the likelihood of being underemployed or working in a low-skilled service job declines sharply as workers age from 22 to 27 .

In terms of family considerations, graduates who are married are less likely to be underemployed (41.5 percent compared to 45.6 percent) or working in a low-skilled service job (6.6 percent compared to 9.2 percent), and this is particularly true among married men. In addition, those graduates with children are more likely to be underemployed (47.4 percent compared to 44.4 percent). Women with children, in particular, are more likely to be working in a low-skilled service job. One potential explanation for these findings is that those who are married or without children have a greater ability to search for better jobs because they have more resources available, or face fewer constraints, and that these factors reduce the likelihood of being underemployed. However, more research is needed to disentangle the potentially complex relationships between gender, family, and the likelihood of underemployment.

Underemployment following the Great Recession also varied significantly across racial and ethnic groups. Compared to white graduates, who have a 44.1 percent likelihood of being underemployed, black and American Indian graduates are 17 percent more likely to be working in a non-college job, while Asian graduates are 5 percent less

13 Goldin, Katz, and Kuziemko (2006) show that women are now much more likely to enroll in and complete college than men, reversing the college gender gap. Fortin, Oreopoulos, and Phipps (2015) demonstrate that the relatively strong academic performance of women compared to men in recent decades stems, in large part, from being better prepared for and focused on college. 
likely. Our estimates also indicate non-white graduates are more likely to be working in low-skilled service jobs, though these differences are generally not statistically significant. Moreover, those of Hispanic origin are 10 percent more likely to be underemployed and 31 percent more likely to be working in a low-skilled service job than non-Hispanics. Looking across genders, the magnitudes of our estimates pertaining to race and ethnicity tend to be larger for men than women. These findings are broadly consistent with other research showing that minorities, particularly black and Hispanic men, tend to suffer the most during recessions (See, e.g., Elsby et al., 2010, 2011; Hoynes, Miller, and Schaller, 2012; and Nunley et al., 2015).

Graduates with a disability are 4.2 percentage points—or 10 percent—more likely to be underemployed than those who are not, and are 1.4 percentage points-or 16 percent-more likely to be working in a low-skilled service job. In both cases, the estimated effects are larger for women than for men.

Graduating with a double major or earning a graduate degree are both associated with a lower likelihood of being underemployed or working in a low-skilled service job. Graduates with a double major are 4.6 percentage points less likely to be underemployed than those with a single major, and are 1.6 percentage points less likely to be working in a low-skilled service job. Those with a graduate degree are 25.2 percentage points less likely to be underemployed than those without, and are 5.2 percentage points less likely to be working in a low-skilled service job. These results are expected as those with two majors or a graduate degree tend to have built more skills, and especially for those with a graduate degree, have developed occupation specific skills and training that may allow them better access to employment opportunities. The reduced likelihood of college 
underemployment for those with a double major or graduate degree is similar for both men and women.

\section{ii. College Major}

The role of college major in finding a good job has become of considerable interest in recent years given the weak labor market following the Great Recession. While not all students are willing and able to complete a degree in any major, some choice is involved, making information about the success of those with certain majors relative to others of value to students and parents. In Tables 6 and 7, we present the predicted probabilities of being underemployed or working in a low-skilled service job, respectively, by college major, holding constant the other variables in our model. Given the large amount of information contained in these tables and the fact that the patterns do not appear to differ widely by gender, we also plot the overall predicted probabilities by college major in Figures 4 and 5. Though there are differences in the rankings of college majors for each measure of underemployment, five broad themes emerge. ${ }^{14}$

First, it is clear that college major is a significant correlate with the probability of being underemployed in the early careers of college graduates. While, on average, 44.6 percent of recent graduates work in a non-college job, underemployment rates range from 70 percent for graduates with a Criminal Justice major to 9.5 percent for those with a Nursing degree. Similarly, while on average, only 8.6 percent of recent college graduates work in a low-skilled service job, this figure ranges from 23.4 percent for those majoring in Leisure and Hospitality to 1.7 percent for graduates with a Civil Engineering major.

14 The Spearman rank correlation of the predicted probabilities of being underemployed and working in a low-skilled service job by college major is 0.57 . 
Second, graduates with college majors that provide technical training and quantitative skills are far less likely to be underemployed than those with majors that tend to be less quantitative in nature. Indeed, for both measures of college underemployment, graduates with majors in the Science, Technology, Engineering, and Mathematics (STEM) fields tend to have some of the lowest predicted probabilities of working in a non-college job. In particular, graduates with any type of engineering major generally fared well in the labor market following the Great Recession. Outside of the traditional STEM majors, those with majors that are quantitatively oriented, such as Accounting, Business Analytics, Economics, and Finance, also tend to have relatively low underemployment rates. By contrast, those with majors in less quantitative subjects such as English Language, Communications, Ethnic Studies, Art History, or Anthropology tend to have relatively high rates of underemployment.

Third, graduates with college majors that provide occupation-specific training tend to be less likely to be underemployed than those with majors providing a more general education. For example, occupation-specific majors like education, engineering, and health-related fields, tended to have much lower rates of underemployment than those with majors in more general fields such as Liberal Arts, Philosophy, or History. This pattern also emerges when examining the outcomes of graduates within a specific academic discipline that may offer both occupation specific majors and majors that are more general. The business field provides a case in point: those with a more targeted major, such as Accounting or Finance, tend to have lower underemployment rates than those with majors that are less directly connected to specific jobs, such as Business Management or General Business. 
Fourth, however, there are some college majors that offer occupation-specific training that tends to be geared toward jobs that do not typically require a bachelor's degree, and graduates with these majors are more likely to be underemployed. For example, those who major in Criminal Justice may be expecting to take jobs in Public Safety (such as a police officer or detective) and those with a Fine Arts or Performing Arts major may be expecting to take jobs in Arts and Entertainment (such as a photographer or dancer). In addition, those with a Leisure and Hospitality major may be trained for a number of jobs that do not to require a college degree, such as a restaurant manager or health and wellness instructor. Further, while those with healthcare-related degrees generally tend to have relatively low underemployment, those with a Medical Technicians major, which likely prepares students to take jobs in the Healthcare Technicians and Assistants category, have relatively high underemployment.

Finally, graduates with college majors geared toward growing parts of the economy are generally less likely to be underemployed. Indeed, the health and education sectors in particular continued to grow through both the downturn and recovery alike, creating job opportunities for people with skills oriented toward these types of jobs. As such, the likelihood of underemployment was fairly low for those with healthcare-related majors, such as Nursing, Pharmacy, and Treatment Therapy. Similarly, those with an education-related major tend to experience below average underemployment in general, though such graduates tend to have higher rates of working in low-skilled service jobs, particularly those who major in Elementary or Early Childhood Education. 


\section{TRANSITIONING TO BETTER JOBS}

A key finding from our empirical analysis is that to some degree, underemployment is a temporary phase for many recent graduates as they transition from school to the labor market. This pattern is particularly evident for those who start their careers working in a low-skilled service job. Indeed, such adjustment is not merely a new phenomenon resulting from the Great Recession-research has shown that underemployment typically falls as new graduates spend time in the labor market, and that this pattern has been occurring for decades (Abel, Deitz, and Su, 2014).

To illustrate this point, in Figure 6, we use estimates from our probit analysis to plot the likelihood of being underemployed (top panel) and working in a low-skilled service job (bottom panel) by age, overall and separately by gender. In both cases, we identify a strong downward trend in the likelihood of working in a non-college job as graduates gain more experience in the labor market. At age 22, when fresh out of college, the likelihood of being underemployed is nearly 50 percent, but this figure falls to around 42 percent by age 27 - a 15 percent decline. Not only are women generally less likely to be underemployed than men at any age, the decline in underemployment is also more pronounced for women than for men. The transition out of low-skilled service jobs is even more striking. At age 22, the predicted probability of working in such a job is about 13 percent, but this figure falls to 6.7 percent by age 27 - a nearly 50 percent decline. The likelihood of working in a low-skilled service job declines at a similar pace for men and women.

To examine more of the details of this transition, in Table 8 we compare the jobs held by Younger Recent Graduates (aged 22 to 23 in 2009) to Older Recent Graduates of 
the same cohort (aged 26 to 27 in 2013). Consistent with our analysis above, a larger share of graduates worked in college jobs in their mid-twenties (59 percent) compared to their early twenties (48 percent). In addition, the composition of jobs held by recent graduates changed within the underemployed occupation categories as these workers aged. The share employed in the lowest paying Low-Skilled Service group drops by half, suggesting that these jobs are temporary for a good number of recent graduates: by the age of 26 or 27 , only 6.6 percent are still working in these types of jobs. The other two groups with the most significant declines include Office and Administrative Support and Sales. Though we cannot identify which jobs graduates tend to move into since our data are cross-sectional in nature - that is, workers may be shifting into other non-college jobs or into college jobs - these figures suggest that many underemployed graduates, particularly those who start in a low-skilled service job, are able to transition to better jobs as they gain more experience in the labor market.

Table 9 presents this same information by gender. In general, these patterns continue to hold when looking at men and women separately. However, while a larger share of women transition out of underemployment to college jobs by their late twenties than men, we find that the share of underemployed graduates working in the high paying Managers and Supervisors occupation category tends to increase more for men than for women. This share rose about one and a half percentage points for men, but edged up only slightly for women. There was also a slight increase in the share of women working in the highest paid category of Information Processing and Business Support, while men experienced almost a full percentage point decline. 
Nonetheless, while underemployment appears to be a temporary phase for many recent graduates who are able to transition to better jobs, a large share of college graduates remain underemployed long after the initial transition into the labor market, and this was particularly true following the Great Recession. Indeed, even in the best of economic times, about one-third of all college graduates work in a non-college job. This figure is fairly stable and does not appear to be particularly responsive to the business cycle. This suggests that at least some college graduates may simply prefer to work in such jobs, either because they like the nature of the work involved, or because of geographic or family considerations, such as taking a lower-skilled job due to a dual labor market search, or while raising children.

\section{CONCLUSIONS}

With the Great Recession and weak labor market that followed in its wake, the prevalence of underemployment among recent college graduates reached highs not seen since the early 1990s. However, contrary to popular perception, our work reveals that most of these newly underemployed workers were not forced into low-skilled service jobs. In fact, many of the jobs such graduates took, while clearly not equivalent to jobs that require a college degree, appeared to be more oriented toward knowledge and skill when compared to the distribution of jobs held by young workers without a college degree. Indeed, our analysis also suggests that underemployment is a temporary phase for many young graduates when they enter the labor market, as it often takes time for newly minted graduates to find jobs suited to their education.

We also find that some college graduates have had much better luck finding a college-level job than others. In particular, the likelihood of being underemployed is 
relatively low for those with quantitatively oriented and occupation-specific majors, and much higher for those with degrees in more general fields. Those with STEM and healthcare-related majors have done particularly well in recent years.

These findings raise some interesting questions about the relative supply and demand for specific skill sets obtained in college, and about the value of some majors relative to others in today's economy. While we do not present our findings in the context of a formal supply and demand model, our work does suggest that certain skills have a higher demand relative to supply than others-such as those majors related to the STEM fields and healthcare. Our findings also raise the specter that degrees in some majors, particularly those that are broad based such as Liberal Arts and General Business, may be less sought-after than others. Further, graduates with some majors seem to more easily fall into jobs that typically do not require their degrees, such as Leisure and Hospitality and Criminal Justice.

Why are graduates with certain majors faring so poorly upon graduation? Is high underemployment for those with these particular majors a consequence of the quality of the students who choose these majors, the quality of the programs and the skills that are developed (or not developed), or is it that the skills that these majors provide are not as valuable as others? More research is required to address these challenging questions.

More generally, today's high level of underemployment is concerning, and raises a number of questions about why it has continued to rise for more than a decade despite ongoing improvement in the labor market. No doubt, the depth of the Great Recession and the relatively lackluster demand for college graduates through the recovery has been a contributing factor. However, there are lingering questions about whether this soft 
demand is a long-term phenomenon, as opposed to cyclical in nature. Indeed, recent research suggests that structural changes in the economy may have reduced the demand for college graduates starting as early as 2000 (Beaudry, Green, and Sand, 2014, 2016). On the supply side, there are questions about whether the quality of students graduating from college has deteriorated in recent years, with some research suggesting that many students gain little knowledge or skill from a college education (Arum and Roksa, 2011, 2014). Our work suggests that these questions are complex, particularly since college graduates with certain skill sets seem to be doing much better in the labor market than others. Further research into these questions would be particularly valuable.

While this work provides more detailed information about the nature of underemployment than has previously been available, it does have its limitations. The most significant limitation is that we cannot fully account for potential unobserved heterogeneity across individuals, such as our inability to control for college grades or the quality of the educational institution attended. In particular, attendance at for-profit colleges increased dramatically during the Great Recession, which may have altered the composition of students graduating during the period we study. Further, we do not have information about innate ability, and so we do not know the value that a college degree is adding relative to one's baseline skill, or how ability factors into which college major people choose. Any of these factors could be contributing to the patterns we observe. In addition, it would be desirable to follow the same individuals over time to capture measures of ability and to track career progression. However, we are not able to do so with the datasets we employ, so we leave these issues for future research. Nonetheless, we believe this work takes an important step forward by providing a more complete 
picture of underemployment in the early careers of college graduates following the Great

Recession. 


\section{REFERENCES}

Abel, Jaison R. and Richard Deitz. 2015. "Agglomeration and Job Matching Among College Graduates," Regional Science and Urban Economics, Vol. 51, pp. 14-24.

Abel, Jaison R., Richard Deitz, and Yaqin Su. 2014. "Are Recent College Graduates Finding Good Jobs?" FRBNY Current Issues in Economics and Finance, Vol. 20, No. 1, pp. 1-8.

Altonji, Joseph G., Erica Blom, and Costas Meghir. 2012. "Heterogeneity in Human Capital Investments: High School Curriculum, College Major, and Careers," Annual Review of Economics, Vol. 4, pp. 185-223.

Altonji, Joseph G., Lisa B. Kahn, and Jamin D. Speer. 2014. "Trends in Earnings Differentials Across College Majors and the Changing Task Composition of Jobs," American Economic Review, Vol. 104, No. 5, pp. 387-393.

Altonji, Joseph G., Lisa B. Kahn, and Jamin D. Speer. 2016. "Cashier or Consultant? Entry Labor Market Conditions, Field of Study, and Career Success," Journal of Labor Economics, Vol. 34, No. S1 (Part 2), pp. S361-S401.

Arcidiacono, Peter. 2004. "Ability Sorting and the Returns to College Major," Journal of Econometrics, Vol. 121, No. 1-2, pp. 343-375.

Arum, Richard and Josipa Roksa. 2011. Academically Adrift: Limited Learning on College Campuses, Chicago: The University of Chicago Press.

Arum, Richard and Josipa Roksa. 2014. Aspiring Adults Adrift: Tentative Transitions of College Graduates, Chicago: The University of Chicago Press.

Autor, David H. and David Dorn. 2013. "The Growth of Low-Skill Service Jobs and the Polarization of the US Labor Market," American Economic Review, Vol. 103, No. 5, pp. 1553-1597.

Beaudry, Paul, David A. Green, and Benjamin M. Sand. 2014. "The Declining Fortunes of the Young Since 2000," American Economic Review, Vol. 104, No. 5, pp. 381386.

Beaudry, Paul, David A. Green, and Benjamin M. Sand. 2016. "The Great Reversal in the Demand for Skill and Cognitive Tasks," Journal of Labor Economics, Vol. 34, No. S1 (Part 2), pp. S199-S247.

Betts, Julian R. 1996. "What Do Students Know About Wages?" Journal of Human Resources, Vol. 31, No. 1, pp. 27-56.

Casselman, Ben. 2013. "College Grads May Be Stuck in Low-Skill Jobs," The Wall Street Journal, March 26. 
Chevalier, Arnaud. 2003. "Measuring Over-Education," Economica, Vol. 70, No. 279, pp. 509-531.

Chevalier, Arnaud and Joanne Lindley. 2009. "Overeducation and the Skills of UK Graduates," Journal of the Royal Statistical Society, Vol. 172, No. 2, pp. 307-337.

Elsby, Michael W., Bart Hobijn, and Ayşegül Şahin. 2010. "The Labor Market in the Great Recession," Brookings Papers on Economic Activity, Spring, pp. 1-48.

Elsby, Michael W., Bart Hobijn, Ayşegül Şahin, and Robert G. Valletta. 2011. "The Labor Market in the Great Recession-An Update to September 2011," Brookings Papers on Economic Activity, Fall, pp. 353-384.

Feldman, Daniel C. 1996. "The Nature, Antecedents and Consequences of Underemployment," Journal of Management, Vol. 22, No. 3, pp. 385-407.

Feldman, Daniel C. and William H. Turnley. 1995. "Underemployment Among Recent Business College Graduates," Journal of Organizational Behavior, Vol. 16, No. S1, pp. 691-706.

Fogg, Neeta P. 2011. "Rising Mal-Employment and the Great Recession: The Growing Disconnection between Recent College Graduates and the College Labor Market," Continuing Higher Education Review, Vol. 75, pp. 51-65.

Fortin, Nicole M., Philip Oreopoulos, and Shelly Phipps. 2015. "Leaving Boys Behind: Gender Disparities in High Academic Achievement," Journal of Human Resources, Vol. 50, No. 3, pp. 549-579.

Galston, William A. 2014. "Welcome to the Well-Educated Barista Economy," The Wall Street Journal, April 29.

Goldin, Claudia, Lawrence F. Katz, and Ilyana Kuziemko. 2006. "The Homecoming of American College Women: The Reversal of the College Gender Gap," Journal of Economic Perspectives, Vol. 20, No. 4, pp. 133-156.

Green, Francis and Yu Zhu. 2010. "Overqualification, Job Dissatisfaction, and Increasing Dispersion in the Returns to Graduate Education," Oxford Economic Papers, Vol. 62, No. 4, pp. 740-763.

Hersch, Joni. 1991. "Education Match and Job Match," Review of Economics and Statistics, Vol. 73, No. 1, pp. 140-144.

Hoynes, Hilary, Douglas L. Miller, and Jessamyn Schaller. 2012. "Who Suffers During Recessions?” Journal of Economic Perspectives, Vol. 26, No. 3, pp. 27-48.

Kahn, Lisa B. 2010. "The Long-Term Labor Market Consequences of Graduating from College in a Bad Economy," Labour Economics, Vol. 17, No. 2, pp. 303-316. 
McKee-Ryan, Frances M. and Jaron Harvey. 2011. “'I Have a Job, But ...': A Review of Underemployment," Journal of Management, Vol. 37, No. 4, pp. 962-996.

Mian, Atif and Amir Sufi, 2010. "Household Leverage and the Recession of 2007 to 2009," IMF Economic Review, Vol. 58, pp. 74-117.

Mian, Atif and Amir Sufi, 2011. "Household Debt and the Weak U.S. Recovery," Federal Reserve Bank of San Francisco Economic Letter, 2011-02, January, pp. 1-5.

Nunley, John M., Adam Pugh, Nicholas Romero, and R. Alan Seals. 2015. "Racial Discrimination in the Labor Market for Recent College Graduates: Evidence from a Field Experiment," The BE Journal of Economic Analysis \& Policy, Vol. 15, No. 3, pp. 1093-1125.

Oreopoulos, Philip, Till von Wachter, and Andrew Heisz. 2012. "The Short- and LongTerm Career Effects of Graduating in a Recession," American Economic Journal: Applied Economics, Vol. 4, No. 1, pp. 1-29.

Peterson, Norman, Michael Mumford, Walter Borman, Richard Jeanneret, Edwin Fleishman, Kerry Levin, Michael Campion, Melinda Mayfield, Frederick Morgeson, Kenneth Pearlman, Marilyn Gowing, Anita Lancaster, Marilyn Silver, and Donna Dye. 2001. "Understanding Work Using the Occupational Information Network (O*NET): Implications for Practice and Research," Personnel Psychology, Vol. 54, No. 2, pp. 451-492.

Ruggles, Steven, Katie Genadek, Ronald Goeken, Josiah Grover, and Matthew Sobek. 2015. Integrated Public Use Microdata Series: Version 6.0 [Machine-readable database]. Minneapolis: University of Minnesota.

Şahin, Ayşegül, Joseph Song, Giorgio Topa, and Giovanni L. Violante. 2014. "Mismatch Unemployment," American Economic Review, Vol. 104, No. 11, pp. 3529-3564.

Stinebrickner, Ralph and Todd R. Stinebrickner. 2014. "A Major in Science? Initial Beliefs and Final Outcomes for College Major and Dropout," Review of Economic Studies, Vol. 81, No. 1, pp. 426-472.

Vedder, Richard, Christopher Denhart, and Jonathan Robe. 2013. "Why Are Recent College Graduates Underemployed?" Center for College Affordability and Productivity Policy Paper, January.

Wiswall, Matthew and Basit Zafar. 2015a. "Determinants of College Major Choice: Identification Using and Information Experiment," Review of Economic Studies, Vol. 82, No. 2, pp. 791-824.

Wiswall, Matthew and Basit Zafar. 2015b. "How Do College Students Respond to Public Information about Earnings?" Journal of Human Capital, Vol. 9, No. 2, pp. 117169. 
Yen, Hope. 2012. "Half of New Grads are Jobless or Underemployed," Associated Press, April 24.

Zafar, Basit. 2011. "How Do College Students Form Expectations?" Journal of Labor Economics, Vol. 29, No. 2, pp. 301-348.

Zafar, Basit. 2013. "College Major Choice and the Gender Gap," Journal of Human Resources, Vol. 48, No. 3, pp. 545-595. 
Table 1: Occupation Categories of Underemployed College Graduates

\begin{tabular}{|c|c|c|c|}
\hline Occupation Category & $\begin{array}{c}\text { Average Wage, } \\
\text { Full-Time } \\
\text { Workers }\end{array}$ & $\begin{array}{l}\text { Average Monthly } \\
\text { Job Postings }\end{array}$ & $\begin{array}{l}\text { Percent Growth } \\
\text { in Postings }\end{array}$ \\
\hline Information Processing and Business Support & $\$ 59,059$ & 188,000 & 63 \\
\hline Managers and Supervisors & $\$ 55,415$ & 359,200 & 122 \\
\hline Public Safety & $\$ 52,567$ & 31,300 & 76 \\
\hline Sales & $\$ 52,474$ & 293,700 & 66 \\
\hline Arts and Entertainment & $\$ 48,765$ & 29,000 & 9 \\
\hline Skilled Trades & $\$ 47,268$ & 158,000 & 162 \\
\hline Office and Administrative Support & $\$ 37,207$ & 351,000 & 57 \\
\hline Healthcare Technicians and Assistants & $\$ 36,223$ & 220,500 & 34 \\
\hline Physical Laborers & $\$ 33,006$ & 275,200 & 285 \\
\hline Low-Skilled Service & $\$ 23,584$ & 271,100 & 133 \\
\hline
\end{tabular}

Note: Average wages are calculated for all workers aged 22 to 65 who usually work at least 35 hours per week for 40 or more weeks per year. Average Monthly Job Postings are calculated for the years 2009 to 2013. Percent Growth in Postings is calculated from mid-2009, the end of the Great Recession, through mid-2014.

Source: U.S. Census Bureau, American Community Survey, 2009-2013; The Conference Board, Help Wanted Online; U.S. Department of Labor, O*NET. 
Table 2: Share of Underemployed Recent College Graduates by Occupation Category

\begin{tabular}{|c|c|c|}
\hline Occupation Category & $\begin{array}{c}\text { Share of } \\
\text { Underemployed } \\
\text { Recent College } \\
\text { Graduates } \\
\end{array}$ & $\begin{array}{c}\text { Share of Young } \\
\text { Workers Without a } \\
\text { College Degree }\end{array}$ \\
\hline Information Processing and Business Support & 11.4 & 2.0 \\
\hline Managers and Supervisors & 13.1 & 7.8 \\
\hline Public Safety & 3.7 & 2.8 \\
\hline Sales & 11.7 & 5.1 \\
\hline Arts and Entertainment & 3.0 & 0.7 \\
\hline Skilled Trades & 2.7 & 8.2 \\
\hline Office and Administrative Support & 25.2 & 15.0 \\
\hline Healthcare Technicians and Assistants & 4.7 & 6.6 \\
\hline Physical Laborers & 5.4 & 24.1 \\
\hline Low-Skilled Service & 19.3 & 27.6 \\
\hline
\end{tabular}

Note: Recent College Graduates are those aged 22 to 27 with a bachelor's degree or higher, while Young Workers are those aged 22 to 27 without a bachelor's degree. All figures exclude those in the military or currently enrolled in school.

Source: U.S. Census Bureau, American Community Survey, 2009-2013. 
Table 3: Share of Underemployed Recent College Graduates by Occupation Category and Gender

\begin{tabular}{|c|c|c|c|c|}
\hline \multirow[t]{2}{*}{ Occupation Category } & \multicolumn{2}{|c|}{$\begin{array}{c}\text { Share of Underemployed Recent } \\
\text { College Graduates }\end{array}$} & \multicolumn{2}{|c|}{$\begin{array}{c}\text { Share of Young Workers Without } \\
\text { a College Degree }\end{array}$} \\
\hline & Male & Female & Male & Female \\
\hline Information Processing and Business Support & 12.1 & 10.7 & 2.1 & 2.0 \\
\hline Managers and Supervisors & 15.1 & 11.4 & 7.7 & 8.1 \\
\hline Public Safety & 5.9 & 1.9 & 3.9 & 1.3 \\
\hline Sales & 12.6 & 11.0 & 4.6 & 5.9 \\
\hline Arts and Entertainment & 3.9 & 2.2 & 0.7 & 0.6 \\
\hline Skilled Trades & 5.0 & 0.8 & 13.1 & 1.0 \\
\hline Office and Administrative Support & 17.8 & 31.3 & 9.3 & 23.4 \\
\hline Healthcare Technicians and Assistants & 2.4 & 6.5 & 1.9 & 13.6 \\
\hline Physical Laborers & 9.2 & 2.3 & 35.5 & 7.5 \\
\hline Low-Skilled Service & 16.1 & 22.0 & 21.3 & 36.7 \\
\hline
\end{tabular}

Note: Recent College Graduates are those aged 22 to 27 with a bachelor's degree or higher, while Young Workers are those aged 22 to 27 without a bachelor's degree. All figures exclude those in the military or currently enrolled in school.

Source: U.S. Census Bureau, American Community Survey, 2009-2013. 
Table 4: Characteristics of Recent College Graduates

\begin{tabular}{|c|c|c|c|c|c|c|}
\hline \multirow[b]{2}{*}{ Variable } & \multicolumn{2}{|c|}{ All Recent Grads } & \multicolumn{2}{|c|}{ Underemployed } & \multicolumn{2}{|c|}{ Low-Skilled Service } \\
\hline & Mean & St. Dev. & Mean & St. Dev. & Mean & St. Dev. \\
\hline \multicolumn{7}{|l|}{ Employment Status } \\
\hline Underemployed & 0.446 & 0.497 & 1.000 & 0.000 & 1.000 & 0.000 \\
\hline Low-Skilled Service & 0.086 & 0.281 & 0.193 & 0.395 & 1.000 & 0.000 \\
\hline \multicolumn{7}{|l|}{ Age and Gender } \\
\hline Age & 25.1 & 1.5 & 24.9 & 1.5 & 24.6 & 1.6 \\
\hline Male & 0.436 & 0.496 & 0.450 & 0.497 & 0.374 & 0.484 \\
\hline \multicolumn{7}{|l|}{ Family Background } \\
\hline Married & 0.234 & 0.423 & 0.199 & 0.399 & 0.157 & 0.364 \\
\hline Children & 0.082 & 0.274 & 0.078 & 0.269 & 0.068 & 0.251 \\
\hline \multicolumn{7}{|l|}{ Race and Ethnicity } \\
\hline White & 0.800 & 0.400 & 0.795 & 0.403 & 0.797 & 0.402 \\
\hline Black & 0.070 & 0.255 & 0.085 & 0.279 & 0.076 & 0.265 \\
\hline American Indian & 0.003 & 0.052 & 0.003 & 0.057 & 0.003 & 0.053 \\
\hline Asian & 0.083 & 0.275 & 0.064 & 0.244 & 0.061 & 0.239 \\
\hline Other Race & 0.045 & 0.207 & 0.053 & 0.223 & 0.063 & 0.243 \\
\hline Hispanic & 0.079 & 0.270 & 0.092 & 0.289 & 0.108 & 0.310 \\
\hline \multicolumn{7}{|l|}{ Disability Status } \\
\hline Disabled & 0.014 & 0.117 & 0.016 & 0.126 & 0.017 & 0.130 \\
\hline \multicolumn{7}{|l|}{ Education } \\
\hline Double Major & 0.121 & 0.326 & 0.117 & 0.321 & 0.107 & 0.309 \\
\hline Graduate Degree & 0.148 & 0.355 & 0.064 & 0.244 & 0.057 & 0.232 \\
\hline $\mathrm{N}$ & \multicolumn{2}{|c|}{$20,233,500$} & \multicolumn{2}{|c|}{$9,031,408$} & \multicolumn{2}{|c|}{$1,744,695$} \\
\hline
\end{tabular}

Note: Recent College Graduates are those aged 22 to 27 with a bachelor's degree or higher. All figures exclude those in the military or currently enrolled in school.

Source: U.S. Census Bureau, American Community Survey, 2009-2013. 
Table 5: Average Marginal Effects from Underemployment and Low-Skilled Service Probit Models

\begin{tabular}{|c|c|c|c|c|c|c|}
\hline & \multicolumn{3}{|c|}{ Underemployed } & \multicolumn{3}{|c|}{ Working in Low-Skilled Service Jobs } \\
\hline & (1) & (2) & (3) & (4) & (5) & (6) \\
\hline & Overall & Male & Female & Overall & Male & Female \\
\hline \multirow[t]{2}{*}{ Male } & $0.012^{* * *}$ & -- & -- & $-0.011^{* * *}$ & -- & -- \\
\hline & $(0.003)$ & -- & -- & $(0.003)$ & -- & -- \\
\hline \multirow[t]{2}{*}{ Age } & $-0.015^{* * *}$ & $-0.013^{* * *}$ & $-0.016^{* * *}$ & $-0.011^{* * *}$ & $-0.009^{* * *}$ & $-0.012^{* * *}$ \\
\hline & $(0.001)$ & $(0.001)$ & $(0.001)$ & $(0.000)$ & $(0.001)$ & $(0.001)$ \\
\hline \multirow[t]{2}{*}{ Married } & $-0.040^{* * *}$ & $-0.044^{* * *}$ & $-0.039^{* * *}$ & $-0.026^{* * *}$ & $-0.033^{* * *}$ & $-0.022^{* * *}$ \\
\hline & $(0.004)$ & $(0.007)$ & $(0.005)$ & $(0.003)$ & $(0.003)$ & $(0.004)$ \\
\hline \multirow[t]{2}{*}{ Children } & $0.029^{* * *}$ & $0.044^{* * *}$ & $0.025^{* * *}$ & $0.007^{* *}$ & 0.004 & $0.010^{* *}$ \\
\hline & $(0.007)$ & $(0.011)$ & $(0.008)$ & $(0.003)$ & $(0.007)$ & $(0.005)$ \\
\hline \multirow[t]{2}{*}{ Black } & $0.075^{* * *}$ & $0.081^{* * *}$ & $0.070^{* * *}$ & 0.007 & 0.011 & 0.003 \\
\hline & $(0.008)$ & $(0.010)$ & $(0.009)$ & $(0.005)$ & $(0.007)$ & $(0.006)$ \\
\hline \multirow[t]{2}{*}{ American Indian } & $0.074^{* * *}$ & 0.058 & $0.082^{* *}$ & 0.003 & $-0.036^{* * *}$ & 0.028 \\
\hline & $(0.025)$ & $(0.037)$ & $(0.033)$ & $(0.015)$ & $(0.008)$ & $(0.024)$ \\
\hline \multirow[t]{2}{*}{ Asian } & $-0.021^{* * *}$ & $-0.035^{* * *}$ & -0.014 & -0.002 & -0.003 & 0.004 \\
\hline & $(0.006)$ & $(0.009)$ & $(0.009)$ & $(0.008)$ & $(0.008)$ & $(0.008)$ \\
\hline \multirow[t]{2}{*}{ Other Race } & $0.039^{* * *}$ & $0.045^{* * *}$ & $0.034^{* * *}$ & $0.018^{* * *}$ & $0.018^{* * *}$ & $0.019^{* * *}$ \\
\hline & $(0.011)$ & $(0.017)$ & $(0.010)$ & $(0.005)$ & $(0.007)$ & $(0.007)$ \\
\hline \multirow[t]{2}{*}{ Hispanic } & $0.045^{* * *}$ & $0.074^{* * *}$ & $0.023^{* * *}$ & $0.026^{* * *}$ & $0.034^{* * *}$ & $0.019^{* * *}$ \\
\hline & $(0.009)$ & $(0.012)$ & $(0.009)$ & $(0.005)$ & $(0.007)$ & $(0.004)$ \\
\hline \multirow[t]{2}{*}{ Disabled } & $0.042^{* * *}$ & $0.030^{*}$ & $0.054^{* * *}$ & $0.014^{*}$ & 0.004 & $0.022^{*}$ \\
\hline & $(0.012)$ & $(0.017)$ & $(0.019)$ & $(0.008)$ & $(0.006)$ & $(0.013)$ \\
\hline \multirow[t]{2}{*}{ Double Major } & $-0.046^{* * *}$ & $-0.051^{* * *}$ & $-0.042^{* * *}$ & $-0.016^{* * *}$ & $-0.013^{* * *}$ & $-0.019^{* * *}$ \\
\hline & $(0.005)$ & $(0.009)$ & $(0.004)$ & $(0.002)$ & $(0.003)$ & $(0.003)$ \\
\hline \multirow[t]{2}{*}{ Graduate Degree } & $-0.252^{* * *}$ & $-0.229^{* * *}$ & $-0.263^{* * *}$ & $-0.054^{* * *}$ & $-0.040^{* * *}$ & $-0.063^{* * *}$ \\
\hline & $(0.006)$ & $(0.007)$ & $(0.006)$ & $(0.002)$ & $(0.003)$ & $(0.003)$ \\
\hline Log Pseudo Likelihood & $-12,227,478^{* * *}$ & $-5,401,846^{* * *}$ & $-6,792,684^{* * *}$ & $-5,503,035^{* * *}$ & $-2,115,863^{* * *}$ & $-3,357,967^{* * *}$ \\
\hline Pseudo R-squared & 0.121 & 0.112 & 0.131 & 0.074 & 0.090 & 0.068 \\
\hline Weighted $\mathrm{N}$ & $20,233,500$ & $8,818,586$ & $11,414,914$ & $20,233,500$ & $8,818,586$ & $11,414,914$ \\
\hline
\end{tabular}

Note: Robust standard errors, clustered at the state level, are reported in parentheses. $* * *, * *$, and $*$ denote statistical significance at the $0.01,0.05$, and 0.10 levels, respectively. Models also include the following controls (coefficients not reported for brevity): individual's college major (73 degree fields), state, and year. Marginal effects for dummy variables represent discrete change from 0 to 1.

Source: U.S. Census Bureau, American Community Survey, 2009-2013. 
Table 6: Probability of Underemployment Among Recent College Graduates by Major

\begin{tabular}{|c|c|c|c|c|c|c|}
\hline Major & Overall & SE & Male & SE & Female & SE \\
\hline Criminal Justice & 0.700 & $(0.011)$ & 0.752 & $(0.017)$ & 0.646 & $(0.013)$ \\
\hline Performing Arts & 0.663 & $(0.013)$ & 0.654 & $(0.025)$ & 0.669 & $(0.012)$ \\
\hline Leisure and Hospitality & 0.640 & $(0.019)$ & 0.669 & $(0.026)$ & 0.613 & $(0.016)$ \\
\hline Anthropology & 0.624 & $(0.019)$ & 0.617 & $(0.026)$ & 0.624 & $(0.024)$ \\
\hline Art History & 0.621 & $(0.021)$ & 0.736 & $(0.047)$ & 0.592 & $(0.023)$ \\
\hline Public Policy and Law & 0.618 & $(0.029)$ & 0.547 & $(0.052)$ & 0.674 & $(0.030)$ \\
\hline Business Management & 0.601 & $(0.006)$ & 0.592 & $(0.011)$ & 0.613 & $(0.007)$ \\
\hline Fine Arts & 0.591 & $(0.009)$ & 0.604 & $(0.012)$ & 0.580 & $(0.012)$ \\
\hline History & 0.575 & $(0.011)$ & 0.581 & $(0.013)$ & 0.573 & $(0.016)$ \\
\hline Animal and Plant Sciences & 0.572 & $(0.019)$ & 0.548 & $(0.031)$ & 0.587 & $(0.024)$ \\
\hline Miscellaneous Technologies & 0.554 & $(0.020)$ & 0.553 & $(0.023)$ & 0.579 & $(0.027)$ \\
\hline Communications & 0.554 & $(0.007)$ & 0.595 & $(0.012)$ & 0.529 & $(0.009)$ \\
\hline Liberal Arts & 0.553 & $(0.022)$ & 0.611 & $(0.018)$ & 0.519 & $(0.030)$ \\
\hline General Business & 0.551 & $(0.013)$ & 0.550 & $(0.014)$ & 0.558 & $(0.014)$ \\
\hline Political Science & 0.548 & $(0.011)$ & 0.538 & $(0.013)$ & 0.562 & $(0.012)$ \\
\hline Marketing & 0.545 & $(0.007)$ & 0.543 & $(0.012)$ & 0.544 & $(0.010)$ \\
\hline Sociology & 0.541 & $(0.017)$ & 0.573 & $(0.030)$ & 0.524 & $(0.016)$ \\
\hline Mass Media & 0.539 & $(0.013)$ & 0.563 & $(0.022)$ & 0.522 & $(0.019)$ \\
\hline Foreign Language & 0.538 & $(0.013)$ & 0.561 & $(0.027)$ & 0.525 & $(0.017)$ \\
\hline Philosophy & 0.537 & $(0.018)$ & 0.563 & $(0.016)$ & 0.507 & $(0.026)$ \\
\hline English Language & 0.534 & $(0.009)$ & 0.571 & $(0.019)$ & 0.513 & $(0.013)$ \\
\hline Agriculture & 0.533 & $(0.030)$ & 0.550 & $(0.032)$ & 0.515 & $(0.042)$ \\
\hline Advertising and Public Relations & 0.511 & $(0.011)$ & 0.547 & $(0.042)$ & 0.493 & $(0.010)$ \\
\hline Medical Technicians & 0.507 & $(0.027)$ & 0.470 & $(0.055)$ & 0.512 & $(0.030)$ \\
\hline Environmental Studies & 0.504 & $(0.021)$ & 0.553 & $(0.020)$ & 0.446 & $(0.032)$ \\
\hline Psychology & 0.503 & (0.009) & 0.537 & $(0.013)$ & 0.488 & $(0.010)$ \\
\hline International Affairs & 0.502 & $(0.024)$ & 0.511 & $(0.033)$ & 0.495 & $(0.026)$ \\
\hline Interdisciplinary Studies & 0.501 & $(0.018)$ & 0.498 & $(0.021)$ & 0.502 & $(0.024)$ \\
\hline Theology and Religion & 0.500 & $(0.019)$ & 0.495 & $(0.025)$ & 0.510 & $(0.031)$ \\
\hline Ethnic Studies & 0.498 & $(0.014)$ & 0.486 & $(0.029)$ & 0.497 & $(0.017)$ \\
\hline General Social Sciences & 0.492 & $(0.035)$ & 0.524 & $(0.068)$ & 0.463 & $(0.032)$ \\
\hline Health Services & 0.488 & $(0.013)$ & 0.537 & $(0.029)$ & 0.475 & $(0.014)$ \\
\hline Miscellaneous Biological Sciences & 0.478 & $(0.013)$ & 0.482 & $(0.026)$ & 0.473 & $(0.018)$ \\
\hline Geography & 0.469 & $(0.030)$ & 0.482 & $(0.045)$ & 0.453 & $(0.036)$ \\
\hline Biology & 0.448 & $(0.009)$ & 0.448 & $(0.011)$ & 0.446 & $(0.011)$ \\
\hline Earth Sciences & 0.446 & $(0.034)$ & 0.438 & $(0.039)$ & 0.463 & $(0.063)$ \\
\hline Engineering Technologies & 0.445 & $(0.020)$ & 0.444 & $(0.022)$ & 0.492 & $(0.049)$ \\
\hline Nutrition Sciences & 0.442 & $(0.025)$ & 0.546 & $(0.068)$ & 0.421 & $(0.025)$ \\
\hline Information Systems and Management & 0.441 & $(0.016)$ & 0.440 & $(0.019)$ & 0.474 & $(0.031)$ \\
\hline Family and Consumer Sciences & 0.440 & $(0.017)$ & 0.453 & $(0.063)$ & 0.431 & $(0.016)$ \\
\hline Miscellaneous Physical Sciences & 0.428 & $(0.042)$ & 0.398 & $(0.047)$ & 0.467 & $(0.056)$ \\
\hline Journalism & 0.425 & $(0.012)$ & 0.452 & $(0.020)$ & 0.406 & $(0.015)$ \\
\hline Commercial Art and Graphic Design & 0.419 & $(0.011)$ & 0.403 & $(0.017)$ & 0.419 & $(0.014)$ \\
\hline Economics & 0.413 & $(0.021)$ & 0.425 & $(0.021)$ & 0.408 & $(0.027)$ \\
\hline Biochemistry & 0.402 & $(0.022)$ & 0.373 & $(0.044)$ & 0.428 & $(0.026)$ \\
\hline Treatment Therapy & 0.394 & $(0.015)$ & 0.483 & $(0.031)$ & 0.358 & $(0.017)$ \\
\hline Architecture & 0.392 & $(0.017)$ & 0.424 & $(0.021)$ & 0.351 & $(0.021)$ \\
\hline Business Analytics & 0.376 & $(0.015)$ & 0.382 & (0.019) & 0.382 & $(0.024)$ \\
\hline Chemistry & 0.371 & $(0.016)$ & 0.406 & $(0.021)$ & 0.339 & $(0.026)$ \\
\hline Finance & 0.370 & $(0.015)$ & 0.368 & $(0.015)$ & 0.388 & $(0.018)$ \\
\hline Social Services & 0.357 & $(0.016)$ & 0.424 & $(0.050)$ & 0.347 & $(0.016)$ \\
\hline Mathematics & 0.330 & $(0.015)$ & 0.350 & $(0.021)$ & 0.311 & $(0.020)$ \\
\hline Pharmacy & 0.322 & $(0.037)$ & 0.312 & $(0.045)$ & 0.325 & $(0.039)$ \\
\hline Physics & 0.318 & $(0.025)$ & 0.356 & $(0.032)$ & 0.238 & $(0.034)$ \\
\hline Miscellaneous Engineering & 0.287 & $(0.016)$ & 0.292 & (0.019) & 0.294 & $(0.026)$ \\
\hline Secondary Education & 0.280 & $(0.014)$ & 0.311 & $(0.017)$ & 0.260 & $(0.017)$ \\
\hline Construction Services & 0.275 & $(0.028)$ & 0.289 & $(0.027)$ & 0.233 & $(0.081)$ \\
\hline General Engineering & 0.263 & $(0.020)$ & 0.267 & $(0.023)$ & 0.277 & $(0.035)$ \\
\hline Accounting & 0.263 & $(0.009)$ & 0.259 & $(0.014)$ & 0.267 & $(0.010)$ \\
\hline Computer Science & 0.262 & $(0.017)$ & 0.260 & $(0.015)$ & 0.316 & $(0.029)$ \\
\hline General Education & 0.245 & $(0.013)$ & 0.290 & $(0.024)$ & 0.231 & $(0.015)$ \\
\hline Industrial Engineering & 0.230 & $(0.023)$ & 0.236 & $(0.032)$ & 0.224 & $(0.038)$ \\
\hline Early Childhood Education & 0.227 & $(0.018)$ & 0.341 & $(0.083)$ & 0.218 & $(0.019)$ \\
\hline Miscellaneous Education & 0.223 & $(0.015)$ & 0.249 & $(0.035)$ & 0.209 & $(0.015)$ \\
\hline Aerospace Engineering & 0.218 & $(0.028)$ & 0.245 & $(0.036)$ & 0.110 & $(0.044)$ \\
\hline Elementary Education & 0.215 & $(0.013)$ & 0.262 & $(0.024)$ & 0.207 & $(0.013)$ \\
\hline Electrical Engineering & 0.205 & $(0.012)$ & 0.209 & $(0.011)$ & 0.211 & $(0.028)$ \\
\hline Mechanical Engineering & 0.203 & $(0.014)$ & 0.211 & $(0.017)$ & 0.176 & $(0.025)$ \\
\hline Chemical Engineering & 0.189 & $(0.021)$ & 0.205 & $(0.025)$ & 0.165 & $(0.028)$ \\
\hline Civil Engineering & 0.187 & $(0.014)$ & 0.188 & $(0.017)$ & 0.191 & $(0.021)$ \\
\hline Computer Engineering & 0.180 & (0.018) & 0.179 & (0.019) & 0.236 & $(0.044)$ \\
\hline Special Education & 0.153 & $(0.020)$ & 0.173 & $(0.066)$ & 0.147 & $(0.020)$ \\
\hline Nursing & 0.095 & $(0.012)$ & 0.159 & $(0.026)$ & 0.087 & $(0.010)$ \\
\hline
\end{tabular}

Source: U.S. Census Bureau, American Community Survey, 2009-2013. 
Table 7: Probability of Working in a Low-Skilled Service Job Among Recent College Graduates by Major

\begin{tabular}{|c|c|c|c|c|c|c|}
\hline Major & Overall & SE & Male & SE & Female & SE \\
\hline Leisure and Hospitality & 0.234 & $(0.010)$ & 0.240 & $(0.019)$ & 0.227 & $(0.011)$ \\
\hline Performing Arts & 0.206 & $(0.017)$ & 0.181 & $(0.037)$ & 0.224 & $(0.013)$ \\
\hline Fine Arts & 0.165 & $(0.009)$ & 0.143 & $(0.012)$ & 0.178 & $(0.009)$ \\
\hline Anthropology & 0.155 & $(0.011)$ & 0.161 & $(0.020)$ & 0.155 & $(0.015)$ \\
\hline Nutrition Sciences & 0.152 & $(0.019)$ & 0.310 & $(0.060)$ & 0.135 & $(0.020)$ \\
\hline Family and Consumer Sciences & 0.152 & $(0.009)$ & 0.128 & $(0.039)$ & 0.158 & $(0.009)$ \\
\hline Liberal Arts & 0.135 & $(0.009)$ & 0.155 & $(0.017)$ & 0.125 & $(0.011)$ \\
\hline Animal and Plant Sciences & 0.134 & $(0.012)$ & 0.135 & $(0.021)$ & 0.132 & $(0.014)$ \\
\hline History & 0.129 & $(0.007)$ & 0.116 & $(0.008)$ & 0.143 & $(0.012)$ \\
\hline Philosophy & 0.126 & $(0.016)$ & 0.129 & $(0.017)$ & 0.118 & $(0.019)$ \\
\hline Early Childhood Education & 0.125 & $(0.013)$ & 0.068 & $(0.049)$ & 0.129 & $(0.012)$ \\
\hline Foreign Language & 0.123 & $(0.011)$ & 0.124 & $(0.030)$ & 0.126 & $(0.012)$ \\
\hline General Social Sciences & 0.122 & $(0.015)$ & 0.093 & (0.019) & 0.145 & $(0.027)$ \\
\hline Theology and Religion & 0.121 & $(0.015)$ & 0.112 & $(0.019)$ & 0.137 & $(0.020)$ \\
\hline Earth Sciences & 0.119 & $(0.029)$ & 0.099 & $(0.028)$ & 0.145 & $(0.059)$ \\
\hline English Language & 0.119 & $(0.006)$ & 0.128 & $(0.011)$ & 0.117 & $(0.007)$ \\
\hline Psychology & 0.118 & $(0.005)$ & 0.108 & $(0.007)$ & 0.124 & $(0.006)$ \\
\hline Environmental Studies & 0.114 & $(0.012)$ & 0.105 & $(0.016)$ & 0.124 & $(0.019)$ \\
\hline Social Services & 0.109 & $(0.010)$ & 0.130 & $(0.039)$ & 0.111 & $(0.009)$ \\
\hline Sociology & 0.108 & $(0.006)$ & 0.111 & $(0.012)$ & 0.109 & (0.008) \\
\hline Art History & 0.106 & $(0.015)$ & 0.227 & $(0.055)$ & 0.090 & $(0.013)$ \\
\hline Miscellaneous Biological Sciences & 0.106 & $(0.009)$ & 0.085 & $(0.010)$ & 0.121 & $(0.012)$ \\
\hline Treatment Therapy & 0.105 & $(0.010)$ & 0.170 & $(0.027)$ & 0.080 & $(0.009)$ \\
\hline Ethnic Studies & 0.102 & $(0.012)$ & 0.093 & $(0.017)$ & 0.109 & $(0.016)$ \\
\hline Elementary Education & 0.100 & $(0.008)$ & 0.086 & $(0.015)$ & 0.103 & $(0.008)$ \\
\hline Interdisciplinary Studies & 0.099 & $(0.007)$ & 0.070 & $(0.010)$ & 0.118 & $(0.011)$ \\
\hline Secondary Education & 0.095 & $(0.007)$ & 0.090 & $(0.011)$ & 0.099 & $(0.009)$ \\
\hline Special Education & 0.093 & $(0.017)$ & 0.090 & $(0.038)$ & 0.096 & $(0.020)$ \\
\hline Communications & 0.092 & $(0.004)$ & 0.089 & $(0.006)$ & 0.096 & $(0.006)$ \\
\hline Mass Media & 0.092 & $(0.011)$ & 0.104 & $(0.017)$ & 0.080 & $(0.014)$ \\
\hline General Education & 0.091 & $(0.007)$ & 0.076 & $(0.014)$ & 0.098 & $(0.009)$ \\
\hline Miscellaneous Physical Sciences & 0.091 & $(0.018)$ & 0.076 & $(0.027)$ & 0.106 & $(0.035)$ \\
\hline Biology & 0.088 & $(0.004)$ & 0.085 & $(0.007)$ & 0.091 & $(0.007)$ \\
\hline Health Services & 0.087 & $(0.006)$ & 0.087 & $(0.009)$ & 0.091 & $(0.007)$ \\
\hline Criminal Justice & 0.085 & $(0.004)$ & 0.068 & $(0.006)$ & 0.105 & $(0.007)$ \\
\hline Geography & 0.084 & $(0.015)$ & 0.086 & $(0.018)$ & 0.080 & $(0.020)$ \\
\hline Political Science & 0.083 & $(0.007)$ & 0.089 & $(0.010)$ & 0.074 & $(0.008)$ \\
\hline Business Management & 0.082 & $(0.005)$ & 0.076 & $(0.005)$ & 0.088 & $(0.006)$ \\
\hline Advertising and Public Relations & 0.078 & $(0.007)$ & 0.065 & $(0.014)$ & 0.084 & $(0.008)$ \\
\hline Commercial Art and Graphic Design & 0.077 & $(0.005)$ & 0.062 & $(0.008)$ & 0.085 & $(0.007)$ \\
\hline Journalism & 0.077 & $(0.006)$ & 0.075 & $(0.011)$ & 0.079 & $(0.008)$ \\
\hline General Business & 0.077 & $(0.005)$ & 0.070 & $(0.006)$ & 0.082 & $(0.008)$ \\
\hline Pharmacy & 0.073 & $(0.017)$ & 0.073 & $(0.023)$ & 0.073 & $(0.027)$ \\
\hline Architecture & 0.072 & $(0.008)$ & 0.074 & $(0.014)$ & 0.066 & $(0.013)$ \\
\hline Miscellaneous Education & 0.070 & $(0.010)$ & 0.049 & $(0.021)$ & 0.080 & $(0.011)$ \\
\hline International Affairs & 0.070 & $(0.008)$ & 0.081 & $(0.014)$ & 0.063 & $(0.008)$ \\
\hline Biochemistry & 0.068 & $(0.011)$ & 0.052 & $(0.022)$ & 0.083 & $(0.016)$ \\
\hline Agriculture & 0.068 & $(0.010)$ & 0.065 & $(0.014)$ & 0.073 & $(0.017)$ \\
\hline Mathematics & 0.062 & $(0.009)$ & 0.056 & $(0.010)$ & 0.066 & $(0.013)$ \\
\hline Marketing & 0.061 & $(0.004)$ & 0.061 & $(0.007)$ & 0.061 & $(0.005)$ \\
\hline Public Policy and Law & 0.060 & $(0.011)$ & 0.025 & $(0.010)$ & 0.089 & $(0.018)$ \\
\hline Chemistry & 0.056 & $(0.009)$ & 0.054 & $(0.012)$ & 0.059 & $(0.016)$ \\
\hline Miscellaneous Technologies & 0.054 & $(0.009)$ & 0.043 & $(0.007)$ & 0.074 & $(0.023)$ \\
\hline Physics & 0.049 & $(0.016)$ & 0.059 & $(0.021)$ & 0.016 & $(0.009)$ \\
\hline Economics & 0.046 & $(0.006)$ & 0.043 & $(0.005)$ & 0.046 & $(0.008)$ \\
\hline Information Systems and Management & 0.045 & $(0.007)$ & 0.036 & $(0.009)$ & 0.068 & $(0.014)$ \\
\hline Engineering Technologies & 0.041 & $(0.007)$ & 0.031 & $(0.007)$ & 0.083 & $(0.028)$ \\
\hline Accounting & 0.038 & $(0.003)$ & 0.033 & $(0.004)$ & 0.043 & $(0.004)$ \\
\hline General Engineering & 0.036 & $(0.006)$ & 0.030 & $(0.006)$ & 0.056 & $(0.019)$ \\
\hline Finance & 0.036 & $(0.003)$ & 0.036 & $(0.004)$ & 0.033 & $(0.004)$ \\
\hline Chemical Engineering & 0.034 & $(0.010)$ & 0.037 & $(0.013)$ & 0.024 & $(0.014)$ \\
\hline Medical Technicians & 0.034 & $(0.009)$ & 0.032 & $(0.021)$ & 0.035 & $(0.010)$ \\
\hline Electrical Engineering & 0.029 & $(0.008)$ & 0.024 & $(0.008)$ & 0.044 & $(0.013)$ \\
\hline Computer Science & 0.027 & $(0.004)$ & 0.018 & $(0.004)$ & 0.065 & $(0.015)$ \\
\hline Computer Engineering & 0.027 & $(0.006)$ & 0.023 & $(0.007)$ & 0.041 & $(0.023)$ \\
\hline Business Analytics & 0.025 & $(0.005)$ & 0.019 & $(0.005)$ & 0.038 & $(0.012)$ \\
\hline Construction Services & 0.025 & $(0.007)$ & 0.019 & $(0.005)$ & 0.080 & $(0.053)$ \\
\hline Nursing & 0.025 & $(0.004)$ & 0.054 & $(0.011)$ & 0.022 & $(0.004)$ \\
\hline Industrial Engineering & 0.024 & $(0.009)$ & 0.019 & $(0.011)$ & 0.033 & $(0.016)$ \\
\hline Miscellaneous Engineering & 0.024 & $(0.005)$ & 0.019 & $(0.006)$ & 0.033 & $(0.008)$ \\
\hline Aerospace Engineering & 0.021 & $(0.009)$ & 0.021 & $(0.010)$ & 0.010 & $(0.009)$ \\
\hline Mechanical Engineering & 0.019 & $(0.004)$ & 0.019 & $(0.004)$ & 0.016 & $(0.006)$ \\
\hline Civil Engineering & 0.017 & $(0.004)$ & 0.016 & $(0.004)$ & 0.015 & $(0.008)$ \\
\hline
\end{tabular}

Source: U.S. Census Bureau, American Community Survey, 2009-2013. 
Table 8: Share of Younger and Older Recent College Graduates by Occupation Category

\begin{tabular}{|c|c|c|}
\hline \multirow[t]{2}{*}{ Occupation Category } & \multicolumn{2}{|c|}{$\begin{array}{l}\text { Share of Underemployed Recent College } \\
\text { Graduates, All }\end{array}$} \\
\hline & Younger & Older \\
\hline Information Processing and Business Support & 5.5 & 5.3 \\
\hline Managers and Supervisors & 5.1 & 5.8 \\
\hline Public Safety & 1.4 & 1.6 \\
\hline Sales & 6.5 & 4.4 \\
\hline Arts and Entertainment & 1.4 & 1.5 \\
\hline Skilled Trades & 1.1 & 1.6 \\
\hline Office and Administrative Support & 12.7 & 10.1 \\
\hline Healthcare Technicians and Assistants & 2.4 & 2.1 \\
\hline Physical Laborers & 2.9 & 2.2 \\
\hline Low-Skilled Service & 12.6 & 6.6 \\
\hline College Jobs & 48.4 & 59.0 \\
\hline
\end{tabular}

Note: Younger Recent College Graduates are those aged 22 to 23 with a bachelor's degree or higher in 2009, while Older Recent College Graduates are those aged 26 to 27 with a bachelor's degree or higher in 2013. All figures exclude those in the military or currently enrolled in school.

Source: U.S. Census Bureau, American Community Survey, 2009 and 2013. 
Table 9: Share of Younger and Older Recent College Graduates by Occupation Category and Gender

\begin{tabular}{|c|c|c|c|c|}
\hline \multirow[t]{2}{*}{ Occupation Category } & \multicolumn{2}{|c|}{$\begin{array}{c}\text { Share of Underemployed Recent } \\
\text { College Graduates, Male }\end{array}$} & \multicolumn{2}{|c|}{$\begin{array}{l}\text { Share of Underemployed Recent } \\
\text { College Graduates, Female }\end{array}$} \\
\hline & Younger & Older & Younger & Older \\
\hline Information Processing and Business Support & 6.3 & 5.4 & 5.0 & 5.1 \\
\hline Managers and Supervisors & 5.0 & 6.4 & 5.2 & 5.3 \\
\hline Public Safety & 2.7 & 2.5 & 0.6 & 0.8 \\
\hline Sales & 7.1 & 5.4 & 6.1 & 3.5 \\
\hline Arts and Entertainment & 2.3 & 2.1 & 0.8 & 0.9 \\
\hline Skilled Trades & 2.2 & 3.1 & 0.4 & 0.4 \\
\hline Office and Administrative Support & 9.8 & 6.9 & 14.6 & 12.6 \\
\hline Healthcare Technicians and Assistants & 1.4 & 1.3 & 3.0 & 2.8 \\
\hline Physical Laborers & 5.7 & 3.8 & 1.2 & 0.8 \\
\hline Low-Skilled Service & 11.0 & 5.7 & 13.6 & 7.4 \\
\hline College Jobs & 46.4 & 57.4 & 49.7 & 60.4 \\
\hline
\end{tabular}

Note: Younger Recent College Graduates are those aged 22 to 23 with a bachelor's degree or higher in 2009, while Older Recent College Graduates are those aged 26 to 27 with a bachelor's degree or higher in 2013. All figures exclude those in the military or currently enrolled in school.

Source: U.S. Census Bureau, American Community Survey, 2009 and 2013. 
Figure 1: Unemployment Among College Graduates

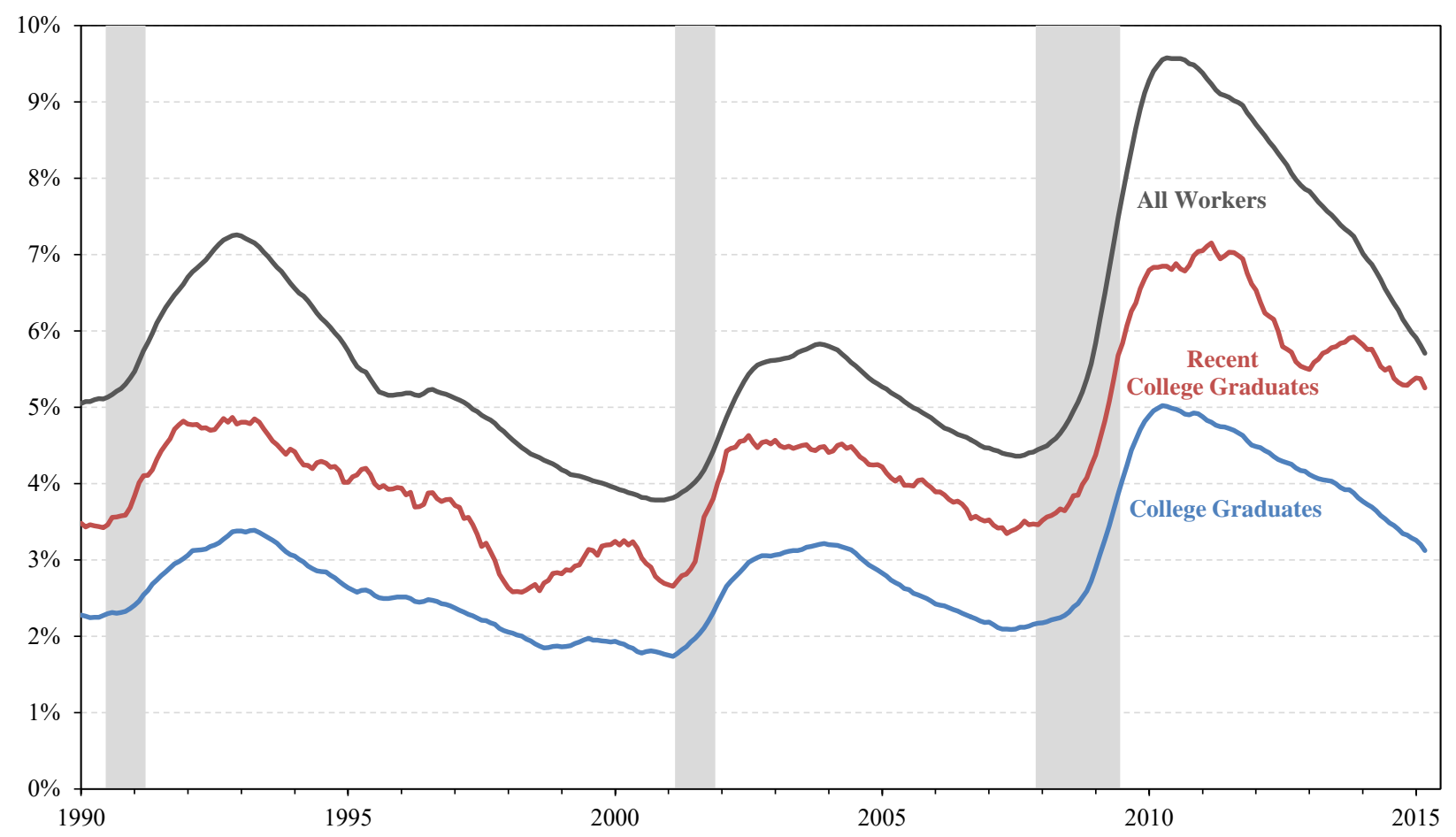

Note: Rates are calculated as a twelve-month moving average. Recent College Graduates are those aged 22 to 27 with a bachelor's degree or higher, while College Graduates are those aged 22 to 65 with a bachelor's degree or higher. All Workers are those aged 16 to 65 regardless of education. All figures exclude those in the military or currently enrolled in school. Shaded area indicates period designated recession by the NBER.

Source: U.S. Census Bureau and U.S. Bureau of Labor Statistics, Current Population Survey. 
Figure 2: Underemployment Among College Graduates

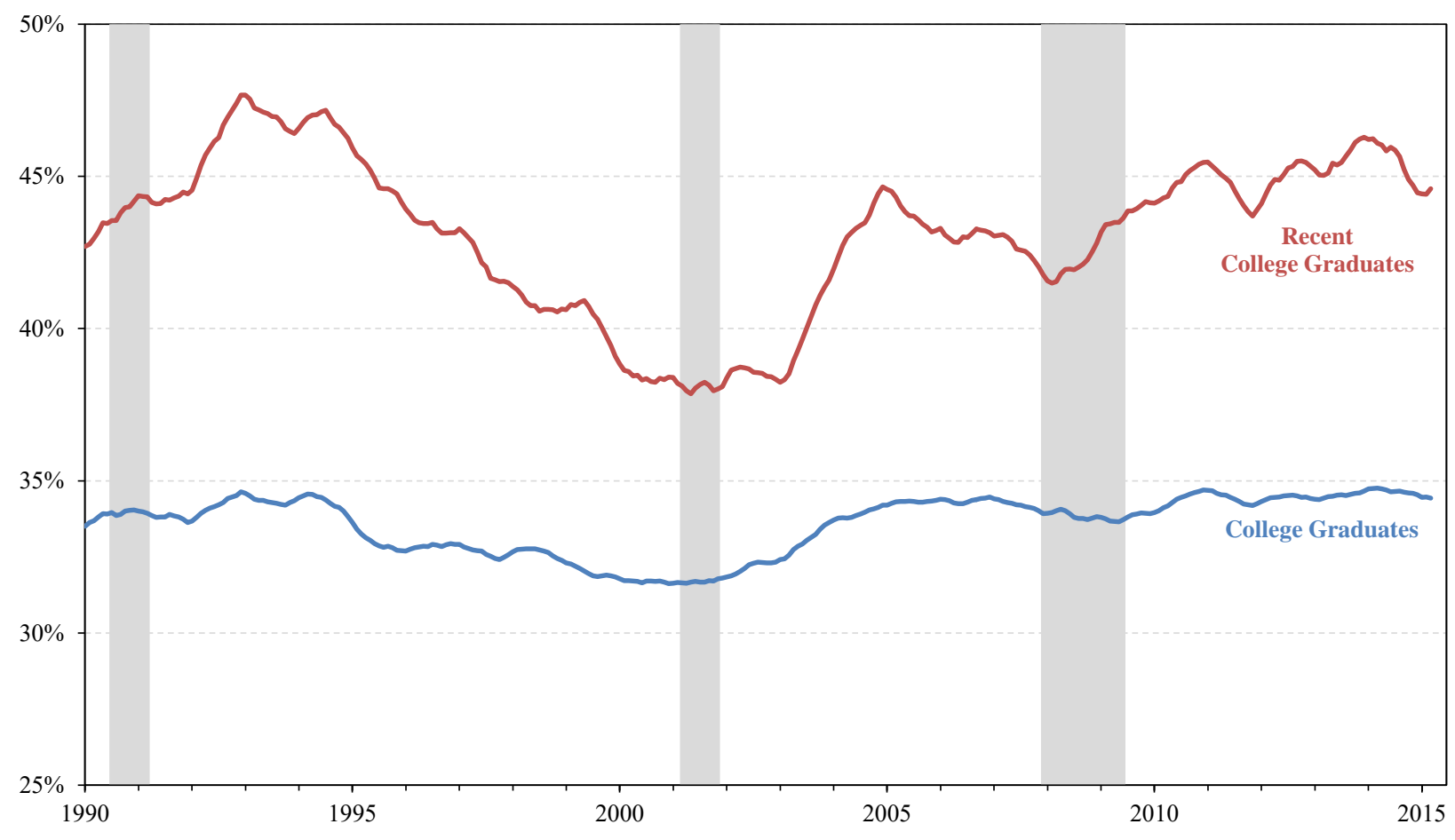

Note: Rates are calculated as a twelve-month moving average. Recent College Graduates are those aged 22 to 27 with a bachelor's degree or higher, while College Graduates are those aged 22 to 65 with a bachelor's degree or higher. All figures exclude those in the military or currently enrolled in school. Shaded area indicates period designated recession by the NBER.

Sources: U.S. Census Bureau and U.S. Bureau of Labor Statistics, Current Population Survey; U.S. Department of Labor, O*NET. 
Figure 3: The Demand for College Graduates Through the Great Recession

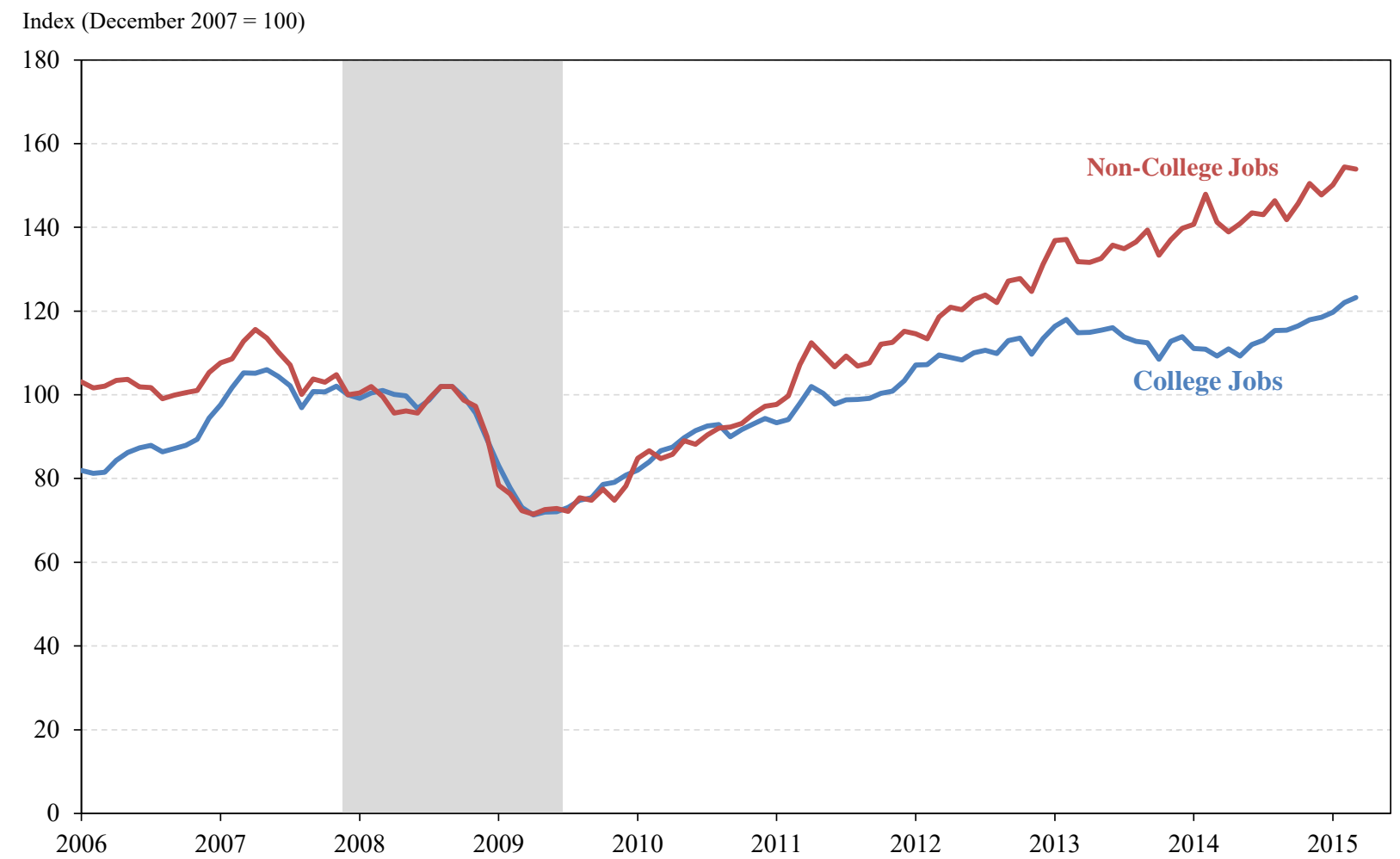

Note: Shaded area indicates period designated recession by the NBER.

Source: The Conference Board, Help Wanted Online; U.S. Department of Labor, O*NET. 
Figure 4: Probability of Underemployment Among Recent College Graduates by Major

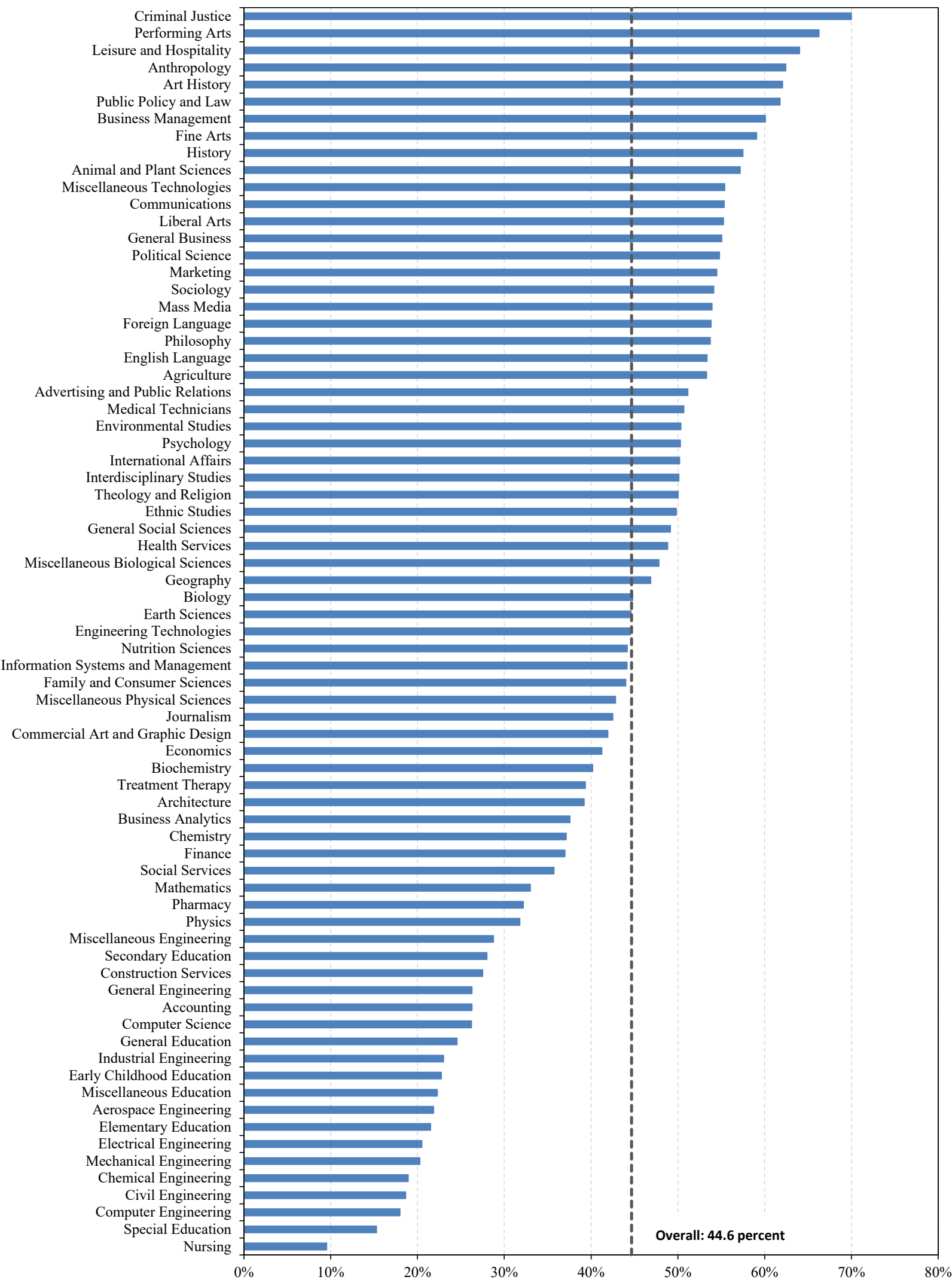

Source: U.S. Census Bureau, American Community Survey, 2009-2013. 
Figure 5: Probability of Working in a Low-Skilled Service Job Among Recent College Graduates by Major

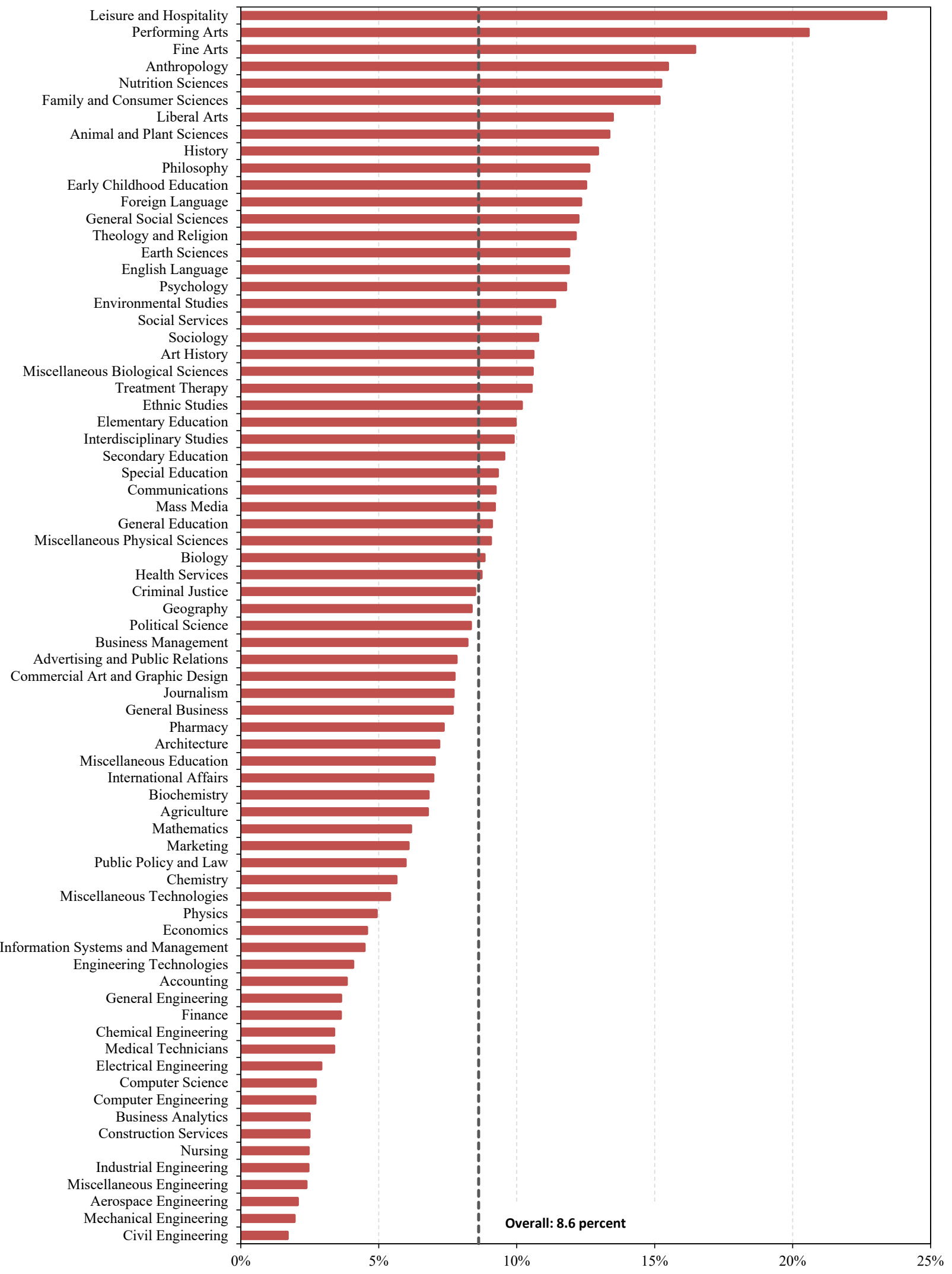

Source: U.S. Census Bureau, American Community Survey, 2009-2013. 
Figure 6: Employment Outcomes of Recent College Graduates by Age

(a) Underemployed

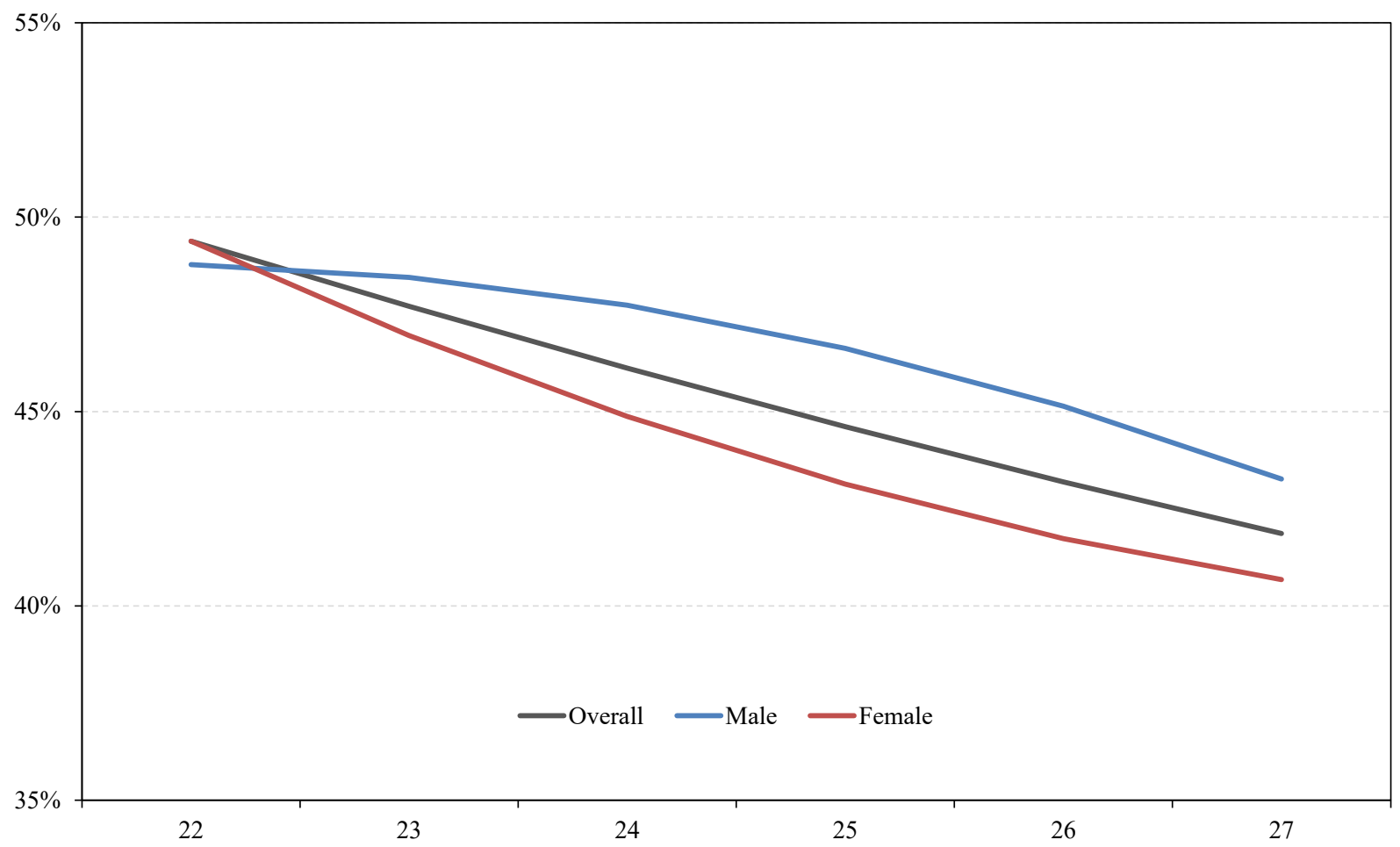

(b) Low-Skilled Service

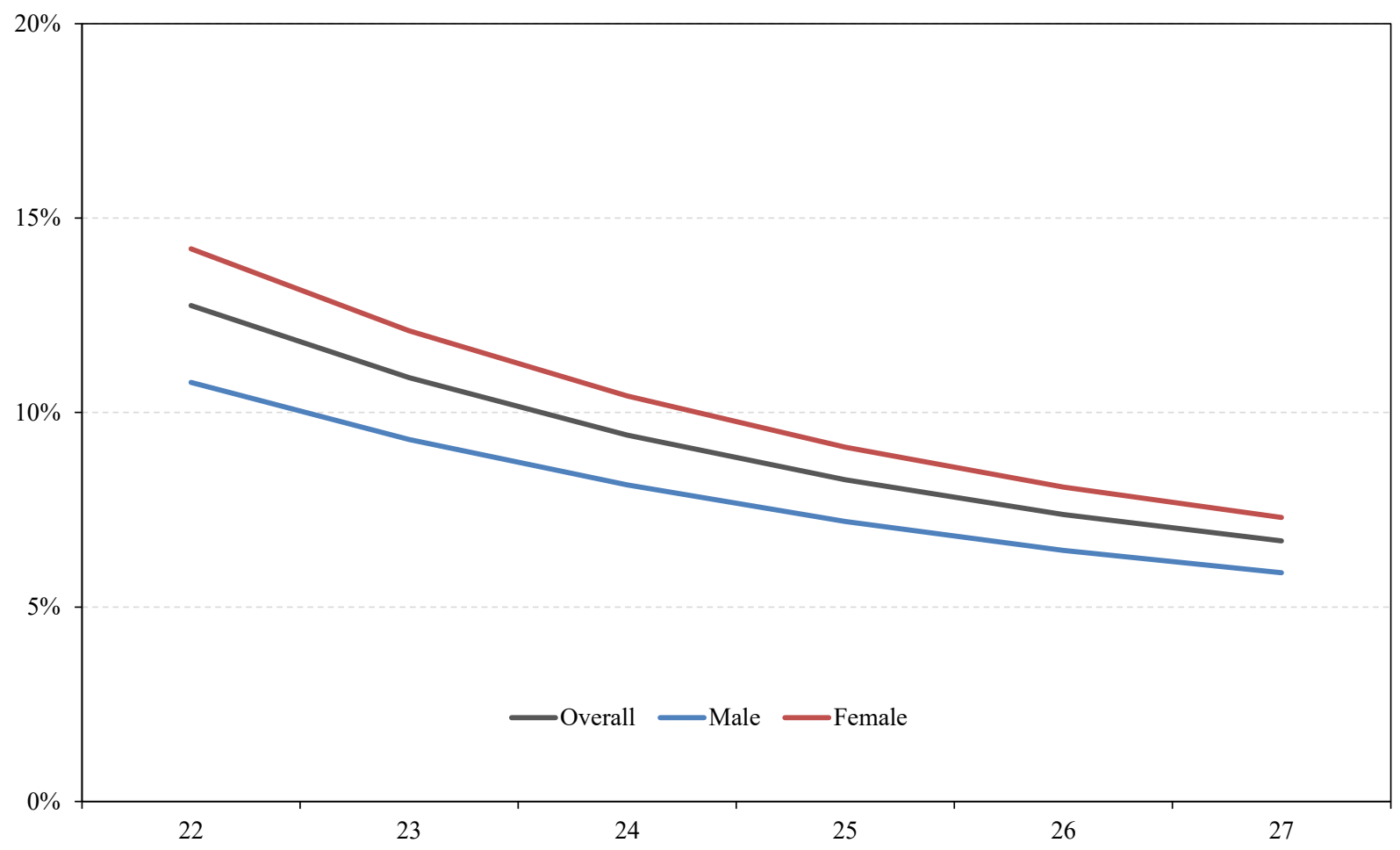

Source: U.S. Census Bureau, American Community Survey, 2009-2013. 